\title{
Evidence from wavelet analysis for a mid-Holocene transition in global climate forcing
}

\author{
M. Debret ${ }^{\text {a, }}$, D. Sebag ${ }^{\mathrm{b}}$, X. Crosta $^{\mathrm{c}}$, N. Massei ${ }^{\mathrm{b}}$, J.-R. Petit ${ }^{\mathrm{a}}$, E. Chapron ${ }^{\mathrm{d}}$ and V. Bout- \\ Roumazeilles $^{\mathbf{e}}$
}

${ }^{a}$ Laboratoire de Glaciologie et de Géophysique de l'Environnement, Université Joseph Fourier, UMR CNRS 5183, BP96, 38402 St Martin d'Hères, France

${ }^{\mathrm{b}}$ Laboratoire de Morphodynamique Continentale et Côtière, Université de Rouen, UMR CNRS/INSU 6143, Department of Geology, 76821 Mont-Saint-Aignan Cedex, France

${ }^{c}$ EPOC, Université Bordeaux I, UMR CNRS 5805, Avenue des Facultés, 33405 Talence, France

${ }^{\mathrm{d}}$ Institut des Sciences de la Terre d'Orléans, Université d'Orléans, CNRS/INSU, Université François Rabelais-Tours, UMR 6113, 1A rue de la Férollerie, F-45071 Orléans cedex 2, France

${ }^{\text {e} P B D S ~ L a b o r a t o r y, ~ U n i v e r s i t e ́ ~ d e ~ L i l l e ~ 1, ~ U M R ~} 8110$ CNRS, 59655 Villeneuve d'Ascq, France

\begin{abstract}
A strong mid-Holocene transition has been identified by wavelet analyses in several sea ice cover records from the circum-Antarctic area, ice core records (Taylor dome, Byrd) and tropical marine records. The results are compared with those previously published in a synthesis of North Atlantic records and with 4 new records from the Norwegian and Icelandic seas and from a coastal site in Ireland. These new records confirm the previous pattern for the North Atlantic area, extend this pattern nearly to the Arctic Circle, and include a continental record. We further tested the possibility of extending this scheme using continental records from South America. The Holocene pattern proposed here confirms the importance of external forcing during the Early Holocene (solar activity: 1000 years cyclicity and 2500 years during the entire Holocene), even if the signal is disturbed by meltwater fluxes. The second part of the Holocene is then marked by the gradual appearance of internal forcing (thermohaline circulation around 1500 years), associated with a stabilisation of the signal. Coupling between ocean and atmosphere seems to play a fundamental role in the observed frequencies which vary accordingly in the Atlantic, circum-Antarctic and Pacific areas. The North Atlantic area seems to be the instigator of thermohaline circulation as shown by its sensitivity to meltwater discharges during the Early Holocene, even though each sector is independent with regards to its frequency content (around 1600 years for Atlantic Area; around 1250 years for Antarctica). The Holocene methane pattern, still under debate [Ruddiman, W.F., 2003a. Orbital insolation, ice volume and greenhouse gases. Quaternary Science Review 22, 1597-1629; Ruddiman, W.F., 2003b. The anthropogenic greenhouse era began thousands of years ago. Climatic Change 61, 261-293], could be explained by a more efficient thermohaline circulation around the mid-Holocene with an anthropogenic effect initiated at $\sim 2500 \mathrm{BP}$ as shown by the inter-hemispheric gradient.
\end{abstract}




\section{Introduction}

Holocene climate variability is different than that of the last glacial period and is the subject of intense research aimed at characterising forcing factors of the observed climate oscillations evidenced in different regions of the world. The Atlantic sector is a key area to improve our knowledge of the climatic system. Indeed its physiography and inter-hemispheric extent provide a connection between the two poles. Located at a key region, the North Atlantic is sensitive to climate variation because it is the starting point of water and salt export.

Moreover this area is surrounded by a continent where ice caps (Greenland and Laurentian ice caps) develop during glacial periods and melt to generate meltwater pulses during the deglaciation and early warm periods. These characteristics are responsible for the dynamic behaviour of the North Atlantic in the transfer, amplification and/or modulation of climatic variation in the global thermohaline circulation mode.

For the last glacial period, a link has been established between the amplitude of fast climatic events and their duration in Antarctica (EPICA community, 2006). However, for the Holocene, the only prominent event that could be seen in both hemispheres, although damped in the Southern Hemisphere, occurred 8200 years ago (Alley et al., 1997). A different approach is therefore necessary.

Debret et al. (2007) have shown that wavelet analysis can be used to identify common spectral signatures for a wide range of paleoclimatic records: marine sediments (Bianchi and McCave, 1999; [Chapman and Shackleton, 2000] and [Giraudeau et al., 2000]), ice cores ([O'Brien et al., 1995] and [Vonmoos et al., 2006]) and dust records (Jackson et al., 2005). In their initial study, limited to the North Atlantic area, they showed that Holocene paleoclimate records do not exhibit continuous 1500 year cycles as indicated by previous studies (e.g. [Bianchi and McCave, 1999] and [Bond et al., 2001]). Indeed, the use of wavelets to detect non-stationarity has made it possible to demonstrate that several Holocene paleoclimatic records include a continuous 2500 -year cycle over the whole period and a 1000 -year cycle during the Early Holocene, sometimes associated with a 1600-year cycle. Identification of the same spectral signature in ${ }^{14} \mathrm{C}$ and ${ }^{10} \mathrm{Be}$ records made it possible to assign these frequencies to external forcing (i.e. solar activity). Despite these evidences, direct evidence between solar activity and weather and climate remains unclear ([Van Geel et al., 1999] and [Beer et al., 2000]). In addition, some paleoclimatic records also show a cyclic period close to 1600 years with an increasing intensity during the Late Holocene. This second spectral signature, not present in solar activity records, has been attributed to internal forcing, likely oceanic-driven as suggested by Broecker et al. (2001) and McManus et al. (1999).

Here we propose to explore the Holocene variability over the North to South Atlantic Ocean and in the circum-Antarctic region in order to characterise Holocene frequency patterns using wavelet analyses. South America is of particular interest because it is connected to water masses coming from the Atlantic and Pacific sectors. We will also propose a possible explanation for methane evolution during the Holocene, which is still under debate (Ruddiman et al., 2008) and of particular interest with regard to global warming. 


\section{Methods}

\subsection{Wavelet transforms}

Wavelet analysis (WA) presents the advantage of describing non-stationarities, i.e. discontinuities and changes in frequency or magnitude (Torrence and Compo, 1998). Redundancy of the continuous wavelet transform is used to produce a time/frequency or time/scale mapping of a power distribution, called the local wavelet spectrum (or scalogram). With respect to classical Fourier analysis, the local wavelet spectrum provides a direct visualisation of the changing statistical properties in stochastic processes with time, a major advantage when studying climatic time series (Witt and Schumann, 2005). In this study, the Morlet wavelet (a Gaussian-modulated sinewave) was chosen for the continuous wavelet transform. More details concerning this approach are available in Debret et al. (2007).

\subsection{Cone of influence}

To avoid edge effects and spectral leakage produced by the finite length of the time series, all series were zero-padded to twice the data length. However, zero-padding causes the lowest frequencies near the edges of the spectrum to be underestimated as more zeros enter the series. The area delineating this region is known as the cone of influence and marks those parts of the spectrum where energy bands are likely to appear to be less powerful than they actually are because of the increasing importance of edge effects.

\subsection{Statistical test}

For all local wavelet spectra, a Monte Carlo simulation was used to assess the statistical significance of peaks. Background noise for each signal was estimated and separated using singular spectrum analysis. Autoregressive modelling was then used for each noise time series to determine the $\operatorname{AR}(1)$ stochastic process against which the initial time series was to be tested. $\operatorname{AR}(1)$ background noise could be either white $(\operatorname{AR}(1)=0)$ or red noise $(\operatorname{AR}(1)>0)$.

\section{Data sets and results}

Main criteria to select the times series used in this study were (1) high resolution data sets, (2) good chronologies to minimize the incertitudes about marine reservoir corrections and/or drifting ages and (3) proxies of fast reacting parameters to reduce dampening effect of the forcing by the internal climate system.

\subsection{Atlantic area}

\subsubsection{Iceland Sea}

Andrews et al. (2003) studied a sequence from a shelf sediment body drilled in the North Iceland margin fronting the Norwegian Sea $\left(66^{\circ} \mathrm{N}, 21^{\circ} \mathrm{W}\right)$ (Fig. 1). The different sedimentological parameters (rock magnetic, grain-size, and sediment properties) were processed using principal component (PC) analysis. Here we present the second PC (Fig. 2 and Fig. 4) interpreted as a proxy of marine paleoproductivity related to solar activity according to Andrews et al. (2003). The scalogram (Fig. 5) presents a frequency content characterised by a marked mid-Holocene transition: unstructured during the Early Holocene, 
the signal intensity increases gradually during the Late Holocene around a frequency band corresponding to a period of 1800 years.

\subsubsection{Norwegian Sea}

Risebrobakken et al. (2003) and Moros et al. (2004) both studied the same sedimentary sequence (MD95-2011) drilled at Rekjanes Ridge in Norwegian Sea (66 $\left.58 \mathrm{~N}, 07^{\circ} 38 \mathrm{E}\right)$ (Fig. 1). The first authors produced a record of $\delta^{18} \mathrm{O}$ variation (from the benthic foraminifere C. teretis) (Fig. 2 and Fig. 4) related to ocean dynamics in the Norwegian Sea via Fram strait. The frequency content (Fig. 5) shows a cyclic period of around 2500 years present throughout the Holocene, another of around 1000 years that governs the variability signal until $5000 \mathrm{BP}$, and a period of 1450 years for the last $5000 \mathrm{BP}$. The second authors propose a record of Ice Rafting (IR) based on a mineralogy study (i.e. Quartz/Plagioclase ratio) (Fig. 1) related to sea ice presence and oceanic conditions over the drilling site (Fig. 2 and Fig. 3). In this IR record, the frequency pattern presents a major cyclic period of around 1700 years (Fig. 5), reaching its maximum intensity after the mid-Holocene (5000-1000 BP).

\subsubsection{South Western Ireland}

McDermott et al. (1998) studied the variations of $\delta^{18} \mathrm{O}$ in a speleothem from southwestern Ireland (Crag Cave) (Fig. 1). The authors suggest that this record reflects North Atlantic temperature (Fig. 2 and Fig. 4) and compare with GISP2 ice cores. The 8.2 ka event preserved in the $\delta^{18} \mathrm{O}$ is now believed to be an artefact (McDermott et al., 2005) and does not impact wavelet analyses. The scalogram (Fig. 5) displays a cyclic period of around 1800 years with a contribution increasing from $5000 \mathrm{BP}$ to present.

\subsubsection{West Africa}

Further south, (deMenocal et al., 2000a) and (deMenocal et al., 2000b) studied a marine sequence (site 658C) drilled off West Africa $\left(20^{\circ} 46 \mathrm{~N}, 18^{\circ} 35 \mathrm{~W} ; 2263 \mathrm{~m}\right.$ water depth) (Fig 1). These authors used planktonic foraminiferal assemblages to reconstruct Holocene Sea Surface Temperature (SST) variations during warm and cold seasons. Here, we present the wavelet analysis for the SST during the warm season, but the results are the same for the cold season (Fig. 2 and Fig. 4). The scalogram (Fig. 5) shows a frequency content dominated by a cycle of around 1500 years during the Late Holocene.

\subsection{Antarctic sites}

\subsubsection{South Atlantic}

Nielsen et al. (2004) studied a sedimentary sequence (TN057) drilled in the South Atlantic area (Weddel Sea; $50^{\circ} \mathrm{S}, 6^{\circ} \mathrm{E} ; 3700 \mathrm{~m}$ water depth) on the path of the Antarctic Circumpolar Deep Water (ACC) and close to the southernmost extension of the North Atlantic Deep Water (NADW) (Fig. 1). These authors reconstructed sea ice presence (SIP) using diatom assemblages (Fig. 3 and Fig. 4). The scalogram of SIP records (Fig. 6) presents a cyclic period of around 2500 years continued throughout the Holocene, two periods of around 1600 and 1000 years that structure the signal during the Early Holocene and the last one of around 1350 years characterising the Late Holocene. 


\subsubsection{Wilkes sea}

Crosta et al. (2007) studied a marine sequence (MD03-2601) drilled in the Circum-Antarctic Ocean (Wilkes sea, $66^{\circ} 03^{\prime} \mathrm{S}, 138^{\circ} 33^{\prime} \mathrm{E}$; $746 \mathrm{~m}$ water depth) (Fig. 1). The authors used two species of diatoms to reconstruct sea ice presence or absence off Adelie Land: species Fragilariopsis kerguelensis (Fig. 3 and Fig. 4), characteristic of the "Permanent Open Ocean Zone" POOZ (Crosta et al., 2005), and the species F. Curta (Fig. 3 and Fig. 5), characteristic of the "Seasonal Sea Ice Zone," SSIZ (Armand et al., 2005). This two paleoclimatic records show different spectral characteristics. The POOZ scalogram (Fig. 6) is organised with cyclic periods of around 1050, 1600 and 2500 years and a mid-Holocene transition marked. The SSIZ scalogram (Fig. 6b) highlights a frequency band corresponding to a period of around 1250 years during the Late Holocene.

\subsubsection{Ice cores}

In this study, we analyse paleoclimatic records of two cores from the Antarctic Ice Sheet. The first isotope record $(\mathrm{D} / \mathrm{H})$ comes from Taylor Dome $\left(77^{\circ} 48^{\prime} \mathrm{S}, 158^{\circ} 43^{\prime} \mathrm{E} ; 2365 \mathrm{~m}\right.$ altitude) located $120 \mathrm{~km}$ from the nearest ocean, and therefore considered as coastal site (Fig. 1). The accumulation rate is 5-7 cm (water equivalent per year), allowing a resolution of 8 years (Steig et al., 1998). The second isotope record $(\mathrm{D} / \mathrm{H})$ is from Byrd $\left(80^{\circ} 01^{\prime} \mathrm{S}, 119^{\circ} 31^{\prime} \mathrm{W}\right)$ located $620 \mathrm{~km}$ from the ocean in West Antarctic, but lower in elevation $(1530 \mathrm{~m})$ than Taylor Dome (Fig. 1). The accumulation rate is $10-12 \mathrm{~cm}$ (water equivalent per year), and the resolution presented by Hammer et al. (1994) is 12 years.

The isotopic records of the Taylor Dome and Byrd ice cores (Fig. 3) both show a significant mid-Holocene transition, but have a different frequency content. The Byrd scalogram (Fig. 6d) shows a frequency corresponding to a cyclic period of around 2400 years continued throughout the Holocene and another of around 1000 years during the Early Holocene. The Taylor dome scalogram (Fig. 6) presents a frequency corresponding to a period of around 1400-1500 years with maximum intensity during the Late Holocene.

\subsection{Southern America area}

Three paleoclimatic records from South America (Bolivia, Peru and Ecuador) are considered: two continental ice cores and a lacustrine sequence.

\subsubsection{Ice cores}

Sajama glacier (Bolivia, $6542 \mathrm{~m}$ asl, $18^{\circ} 06^{\prime} \mathrm{S}, 68^{\circ} 53^{\prime} \mathrm{W}$ ) covers an extinct volcano bordering the northern desert of the Altiplano which has an average altitude of $3700 \mathrm{~m}$ and an area of $205000 \mathrm{~km}^{2}$ (hosting Lake Titicaca) (Fig. 1). (Thompson et al., 1998) and (Thompson et al., 2000) propose a reconstruction of local paleotemperature from a D180 ice core record (Fig. 4). Huascaran glacier (Peru, $6048 \mathrm{~m}$ asl, $9^{\circ} 07^{\prime} \mathrm{S}, 70^{\circ} 50^{\prime} \mathrm{W}$ ) is located in the central north Andes of Peru in the Cordillera Blanca (Thompson et al., 1995). We present the $\mathrm{NO}_{3}$ record during the Holocene (Fig. 4). The $\mathrm{NO}_{3}$ record (Thompson et al., 2000 L.G. Thompson, E. Mosley-Thompson and K.A. Henderson, Ice-core palaeoclimate records in tropical South America since the Last Glacial Maximum, Journal of Quaternary Sciences 15 (2000), pp. 377-394. Thompson et al., 2000) can be considered as a marker of changes in vegetation in the Amazon basin. The scalograms of these two records (Fig. 7) show a similar frequency 
content, marked by a cyclic period of around 1500 years for which the intensity increases during the Late Holocene.

\subsubsection{Lacustrine sequences}

A little further north, Rodbell et al. (1999) and Moy et al. (2002) studied the lacustrine sediments from Laguna Pallcacocha located in Ecuador ( $4200 \mathrm{~m}$ asl, $\left.2^{\circ} 46^{\prime} \mathrm{S}, 7^{\circ} 14^{\prime} \mathrm{W}\right)$ (Fig. 1). The authors used sediment colour in order to reconstruct El Nino activity during the Holocene (Fig. 4). In agreement with Moy et al. (2002), the scalogram of this El Nino record shows a frequency corresponding to a cyclic period of around 1890 years during the Late Holocene (Fig. 7).

\section{Interpretation of paleoclimatic records and spectral signatures}

\subsection{Spectral imprint of solar origin - Early Holocene}

This characteristic spectral signature (continuous cyclic period of 2500 years and a period of 1000 years during the Early Holocene) was recognised in several sedimentary records of the North Atlantic area (Debret et al., 2007), notably in the IRD record (Bond et al., 2001). The solar origin of this imprint is shown by the ${ }^{10} \mathrm{Be}$ record from Greenland ice core (Vonmoos et al., 2006) (Fig. 6), ${ }^{14} \mathrm{C}$ production rates (Reimer in Bond et al., 2001) and wavelet analysis. Moreover, sunspot numbers (Solanki et al., 2004) and the residual ${ }^{14} \mathrm{C}$ give the same results (not shown here). The results of the various proxies presented here are used to identify the fingerprint in records distributed around the Atlantic and Antarctic areas and confirm solar forcing.

The solar imprint is found in the Norwegian $\delta^{18} \mathrm{O}$ record (Risebrobakken et al., 2003) which shows frequencies corresponding to periods of around 1000-2500 years during the Early Holocene (Fig. 5). However this is not enough to explain the entire record, mainly for the Late Holocene. Although a multi-decadal variability is observed,Risebrobakken et al. (2003) explain that their signal processing (Fourier Transform) does not allow identification of a periodic behaviour of the climate on the centennial and millennial scales. They dismiss a possible link with solar activity to explain Holocene variability. However, here the use of wavelet analysis allows identification of millennial solar forcing at least for the first part of the Holocene.

In the South Atlantic ocean, the sea ice record (Nielsen et al., 2004) presents solar periodicity clearly identified with a continuous cycle of around 2500 years and with two others of around 1000 and 1660 years only during the Early Holocene (Fig. 6). Again, for the first part of the Holocene (until 5000 BP), sea ice fluctuations could be explained by solar activity variations.

In the coastal Antarctic Ocean, the sea ice record (Crosta et al., 2007) shows a very similar frequency pattern (Fig. 6). The POOZ species record shows a solar imprint during the Early Holocene, which is also in agreement with the authors for the first part of the Holocene (until $\sim 4000$ BP).

In Antarctica, there is a clear solar imprint in the isotopic record from Byrd. This time, it is sufficient to explain all the Holocene millennial variability (Fig. 6). 
In conclusion, we find the solar imprint in both hemispheres. In a few cases, as for the Byrd $\mathrm{D} / \mathrm{H}$ record (Antarctica), this solar influence is sufficient to explain millennial scale signal variability. However, in other cases ([Risebrobakken et al., 2003], [Nielsen et al., 2004] and [Crosta et al., 2007]), the solar imprint is limited to the Early Holocene and solar forcing cannot alone explain the variability of the Holocene signal on the millennial scale.

\subsection{Spectral imprint of internal origin - Late Holocene}

Our analysis of the Norwegian $\delta^{18} \mathrm{O}$ record (Risebrobakken et al., 2003) shows that the Late Holocene is characterised by a spectral imprint similar to that identified by Debret et al. (2007) in records attributed to marine and internal forcing (Fig. 5). This result is quite consistent with the authors' conclusion that emphasised an increasing influence of Atlantic circulation during this period.

In the same core, a frequency corresponding to a period of around 1700 years appears in IR records (Moros et al., 2004) during the Late Holocene. This might indicate that the lithic debris carried by sea ice is regulated by a forcing factor of internal origin (oceanic and atmospheric) (Fig. 5). This internal imprint can also be identified in the ${ }^{18} \mathrm{O}$ record of an Irish speleothem from the coastal site of Crag Cave (McDermott et al., 1998), thus influenced by the nearby ocean (Fig. 5).

This internal imprint can be further identified in the Iceland paleoproductivity record (Andrews et al., 2003), which means that the statistical parameter studied (PC2) would not be directly controlled by solar activity as initially supposed by the authors. On the other hand, we suggest that oceanic forcing could control marine productivity on the millennial time scale (Fig. 5).

A little further south, an SST record from the eastern Atlantic off NW Africa ([deMenocal et al., 2000a] and [deMenocal et al., 2000b]) demonstrates a clear oceanic imprint with the 1500-year internal period well expressed during the Late Holocene.

The connection is established with the southern hemisphere when analysing the sea ice records ([Nielsen et al., 2004] and [Crosta et al., 2007]). The frequency pattern is similar for the two records. During the Early Holocene, the signal variability seems to be controlled by solar forcing (see above). In contrast, during the Late Holocene since 4000-5000 BP, the SIP record (Nielsen et al., 2004) and SSIZ record (Crosta et al., 2007) reflect an internal forcing (Fig. 6). But the frequencies are quite different with periods of 1250/1350 years in the Southern ocean instead of the $\sim 1600$ years period in the North Atlantic.

A comparable frequency (corresponding to a period of 1390 years) is identified in the isotopic record of Taylor Dome, with a maximum intensity around 5000 BP. This Antarctic core is located near the coast, under the influence of the ocean (Fig. 6). The spectral imprint appears, however, different from those identified in the Atlantic sector.

In the Eastern Pacific region, the analysis of Paleoclimatic records of Peru and Bolivia (Huascaran and Sajama ice cores; Thompson et al., 2000) indicates an internal imprint with an increasing intensity with periods of around 1400 and 1500 years during the Late Holocene (Fig. 7). The Ecuador lake record (Moy et al., 2002) shows a mid-Holocene significant transition marked by the appearance of a period close to 2000 years (1900 years). This 
supports an internal forcing factor different than those observed in the circum-Atlantic and Antarctica areas (Fig. 7).

It is therefore possible to specify the Holocene pattern proposed by Debret et al. (2007). Characteristic across the Atlantic, this pattern is marked by a dominant solar imprint (periods of 1000, 1600 and 2500 years) during the Late Holocene, followed by the strengthening of an internal imprint (period of 1250-1600 years) of maximum intensity since 5000 BP. This Late Holocene scheme can be extended to the circum-Pacific and Antarctica areas with a slightly different frequency pattern (1300 years for the circum-Antarctic sector and 1900 years for the Pacific sector, corresponding to the period of around 1600 years for the Atlantic sector).

\section{Worldwide pattern?}

The results presented reveal two distinct spectral imprints in various paleoclimatic records throughout the world ocean. They also make it possible to attribute several of these imprints (1000 and 2500 years) to direct solar forcing. On the other hand, the second imprint (around 1600 years) is missing in records related to cosmogenic isotopes. It has been assigned to internal forcing with an oceanic and/or atmospheric influence that could not be determined because this imprint is present in both marine (e.g. Giraudeau et al., 2000) and continental (e.g. continental ice cores, speleothems, and lacustrine sediments) records. Recent literature provides many arguments involving ocean circulation and/or an ocean/atmosphere coupling to explain the Holocene climatic variability.

\subsection{Trans-Atlantic variability}

The Norwegian Sea record ( $\delta^{18} \mathrm{O}$ in Risebrobakken et al., 2003; IR in Moros et al., 2004) sites are located northward (i.e. upstream) of the natural Icelandic threshold via which the Meridional Overturning Circulation (MOC) flows to the Arctic region. This threshold played an important role during the last glacial period (Rahmstorf, 2002), but its impact seems negligible during the Holocene despite the significant rise in sea level until $5000 \mathrm{BP}$. Indeed, $\delta^{18} \mathrm{O}$ and IR records both show spectral signatures comparable to those identified elsewhere.

Thus, the $\delta^{18} \mathrm{O}$ measured by Risebrobakken et al. (2003) in the Norwegian Sea has a spectral signal similar to the IRD record (Fig. 5) studied by Bond et al. (2001) for the North Atlantic (continuous 2500-year, Early Holocene 1000-year and Late Holocene 1450-year periodicities; in Debret et al., 2007). In contrast, the spectral signal from the Ice Rafting record considered by Moros et al. (2004) presents a different spectral pattern (Late Holocene: 1700-year periodicity). The record considered by Moros et al. (2004) concerns IRD prompted by sea ice and logically more sensitive to ocean forcing, whereas the IRD series studied by Bond et al. (2001) is related to icebergs, and therefore more sensitive to the role of solar activity on coastal glacier melting. Indeed, these glaciers are the main suppliers of icebergs during an interglacial stage, and their response to rapid climate change is almost instantaneous on the millennial scale. For example, in Greenland, the Jakobshavn, Kangerdlugssuaq and Helheim glaciers have increased their speed by $50 \%$ on a decadal scale, in association with global warming ([Joughin et al., 2004], [Joughin, 2006] and [Rignot and Kanagaratnam., 2006]), and each acceleration was preceded by a phase of major calving (Ekström et al., 2006). This probably explains why there is solar forcing in Bond's IRD record during the Early Holocene (Debret et al., 2007), while Moros's IRD record is related to internal forcing for which the influence became dominant during the Late Holocene. In this regard, note that this record has a spectral signal very similar to that of the Coccolith record studied by Giraudeau et al. (2000) 
south of Iceland (in Debret et al., 2007), and that the authors precisely cite surface circulation instabilities to explain their paleoclimatic proxies.

However, the nature of this forcing is open to discussion. Indeed, the $\delta^{18} \mathrm{O}$ record studied by McDermott et al. (1998) was measured on a speleothem in SW-Ireland. This record has been related to temperature variations and has a spectral signal (1600-year periodicity after the mid-Holocene transition) very similar to those already identified (Debret et al., 2007) in the loessic sequence studied by Jackson et al. (2005) and the record of sodium flux related to sea spray studied by O'Brien et al. (1995). These continental records seem to indicate, therefore, that a change via sea ice affected the atmospheric conditions in the North Atlantic area during the mid-Holocene transition. Jennings et al. (2002) indicate an onset toward Neoglacial conditions with a significant increase in sea ice cover at around $4700 \mathrm{BP}$. This implies a coupled ocean/atmosphere to explain the growing influence of internal forcing during the Late Holocene (Debret et al., 2007). The mid-Holocene transition is also highlighted by Turney et al. (2005) in a continental record from an Irish bog tree population.

Among the North Atlantic records we have introduced in this study, the paleoproductivity indicator (PC2) from Andrews et al. (2003) confirms the thermohaline circulation impact with a frequency of internal origin. This record of paleoproductivity is consistent with the record of Giraudeau et al. (2000) from a location farther to the south.

In addition, several records made it possible to extend this scheme to the tropical Atlantic. Thus, wavelet analysis of the terrigenic record from Cape Ghir $\left(31^{\circ} \mathrm{N}\right.$; Kuhlmann et al., 2004) shows a cyclic period close to 1000 years during the Early Holocene, which reflects the influence of solar forcing. In addition, these authors report a drastic change of terrigenous inputs in Cape Yubi $\left(27^{\circ} \mathrm{N}\right)$ during the mid-Holocene concomitant with changes in fluxes of terrigenous particles off Cape Blanc $\left(20^{\circ} \mathrm{N}\right)$ (deMenocal et al., 2000a). As in the North Atlantic, these records indicate that the mid-Holocene transition is marked by the strengthening of internal forcing. Its origin could be ocean/atmosphere coupling which probably involves the West African Monsoon controlling the terrigenous input variability in the region.

In the same way, the analysis of the West-African SST record (deMenocal et al., 2000b) shows the impact of this internal forcing, in agreement with the interpretations of these authors. They stated that temperature variations resulted from southward increased advection of cooler temperate or subpolar waters to this subtropical location or from enhanced regional upwelling.

The SST record off the coast of Africa made it possible to identify a clear connection between the paleoclimatic records from the North and Tropical Atlantic, reflecting dominant solar forcing during the Early Holocene and a drastic mid-Holocene transition related to the strengthening of internal forcing. This forcing, present from the sub-Arctic to the Equator during the Late Holocene, probably involves various regional mechanisms directly or indirectly associated with the Thermohaline Circulation (THC). Wavelet analysis (not shown in this study) of a record of the activity of the thermohaline circulation off Brazil at $4^{\circ} \mathrm{S}$ (Arz et al., 2001) shows a significant transition during the mid-Holocene. Indeed, the frequency content highlights cycles close to 1100 years related to solar cycles, near the value of 1500 years for internal forcing. However, a 2000-year cycle present throughout the record shows the importance of possible regional effects. 


\subsection{Circum-Antarctic variability}

Around Antarctica, Hodell et al. (2001) and Nielsen et al. (2004) were the first to study the variations of Holocene sea ice cover in the South Atlantic ocean. The WA of Nielsen's SIP record show a very clear solar component (continuous period of 2500 years and a period of 1000 years during the Early Holocene) similar to the ones found in the cosmogenic isotope records (Debret et al., 2007). For the Early Holocene, this correspondence is consistent with Hodell et al. (2001) who called on orbital forcing to explain the variations in extent of sea ice in the Weddell Sea. However solar activity cannot reconstitute all the signal variability, especially during the Late Holocene. The 1350-year period involves another forcing factor, which can be found in the records of Crosta et al. (2007) (Wilkes sea, East Antarctica; Fig. 1). The solar forcing may not be related to the assumptions of Hodell et al. (2001) that link (i.e. positive feedback) sea ice cover and moisture in Africa for the mid-Holocene transition. Note that the frequencies identified off the coast of Africa and Antarctica are close but significantly different, corresponding to periods of 1500 years and 1350 years respectively, and that the latter does not correspond to any value already observed in the North Atlantic area. It is highly possible that the two records were initiated by the restart of the thermohaline circulation on its stable frequency, but that they then responded differently to this initial forcing.

The paleoclimatic proxies from sedimentary sequences are often compared to the records of ice cores, a reference for the global climate. Our WA on the isotopic records from Taylor Dome and Byrd sites shows different patterns. Though both records registered global forcing, their influence is regionally limited. At the Taylor Dome coastal site, the ocean influence likely overwhelmed the solar forcing that structured climate variability during the Early Holocene (Fig. 6). In contrast, at the Byrd continental site, solar forcing is registered without the overlap of any internal signal (Fig. 6). These results show that a single proxy (e.g. isotope $\mathrm{D} / \mathrm{H}$ related to temperature) can register a comprehensive forcing (external or internal), but for which the influence is differently expressed regionally depending on the geographical location of sites.

Wavelet analysis can be used to draw up a circum-Antarctic pattern, which is broadly consistent with those established for the Atlantic Area, even if the detailed characteristics are slightly different. Around 5000 years BP, the records show a drastic change that reflects the passage of solar forcing to internal forcing. Even if all the records do not permit a frequency analysis because of low temporal resolution, they all clearly showed a significant change around this period. Ciais et al. (1992) noted a regional climatic warming of $2{ }^{\circ} \mathrm{C}$ around $4500 \mathrm{BP}$ based on western Antarctic ice cores. On land, the expression of the mid-Holocene climate optimum has been reported from numerous sources, especially in marginal coastal locations of Antarctica (e.g. [Berkman et al., 1998] and [Ingolfsson et al., 1998]). Salvi et al. (2004) showed a dramatic fall of the paleoproductivity after 5000 years BP in the western Ross sea. Increasing humidity stimulated glacier advance on James Ross Island (Björck et al., 1996) and there were glacier advances in South Georgia (Clapperton and Sudgen, 1988). The period 5500-5000 BP witnessed significant cooling, polar climate conditions and maritime glacier activity in Antarctica (Noon et al., 2003). The end of the mid-Holocene climate optimum is evidenced a little later at 4700 years BP in Palmer Deep (Domack et al., 2001).

Finally, as elsewhere in the studied areas, Antarctic climate variability appears to be forced by solar activity during the Early Holocene (up to 5000 years BP) and by internal forcing during the Late Holocene (since 5000 years BP). 


\subsection{The case of South America}

Records of both ${ }^{18} \mathrm{O}$ and $\mathrm{NO}_{3}{ }^{-}$in Sajama (Bolivia) and Huascaran (Peru) glaciers show a set of frequencies with a pattern similar to that previously observed in the Atlantic sector. Indeed, cycles of 1500 years and 1700 years are observed until the mid-Holocene in the Sajama and the Huascaran ice cores respectively (Fig. 7). Thompson et al. (2000) explained that the Sajama and Huascaran glaciers get their main source of moisture from the Atlantic. Water vapour is advected from East and North-East over the Amazon basin. Thus it seems logical that both isotopic records present Atlantic cyclicities ([Hoffmann et al., 2003] and [Hoffmann, 2003]). The case of $\mathrm{NO}_{3}{ }^{-}$is more complex. Although the sources of $\mathrm{NO}_{3}{ }^{-}$are not well defined, studies indicate that the tropical rainforest and forests soils may be the main source of atmospheric nitrogen species such as $\mathrm{NO}$ and $\mathrm{NH}_{3}$, which are precursors for $\mathrm{NO}_{3}{ }^{-}$and $\mathrm{NH}_{4}{ }^{+}$arriving as aerosol ([Robertson and Tiedje, 1988] and [Talbot et al., 1988]). Thompson et al. (2000) propose that the beginning of the Holocene could reflect successive changes of vegetation, which would have required an adjustment period of 2000 years for a maximum regrowth of the virgin forest after the marked reduction during the Last Glacial Maximum. The frequency pattern clearly suggests internal forcing. Indeed it is strongly possible that the establishment of the THC around its stable frequency resulted in an atmospheric rearrangement, as in the North Atlantic, which had a regulating effect on the inflow of moisture in the Amazon Basin.

A little farther north, in Ecuador, the study of a high elevation lake, Laguna Pallcacocha ([Rodbell et al., 1999] and [Moy et al., 2002]), highlighted the appearance of a cycle of around 1900 years since 5000 years BP when the current El Nino cyclicity and intensity was established (ENSO). This cycle is different from those identified to date (Fig. 7). For example, neither the Sajama nor the Huascaran records show this period of around 1900 years despite the vicinity of the lake and the ice records. This indicates that the Andes are an important climatic barrier between the two study areas. Disregarding possible stratigraphic biases, the different cyclicities recorded in Ecuador (1900-2000 years) and in the Southern ocean (1250-1350 years) demonstrate that the ENSO had a weak impact on Antarctic sea ice cover during the Holocene, which contradicts studies on the modern links between the two areas (Cai and Baines, 2001). Some studies indeed show that there is a link between the sea ice cover and SOI (ENSO) on the interannual or decadal scale (Simmonds and Jacka, 1995). It seems that this is not the case on the millennial scale. The only common point concerns the simultaneous strengthening of their respective frequency since 5000 years BP. Thus, the variability of El Nino events presents a specific frequency, but its registration coincides with the mid-Holocene transition related to the reloading of THC and atmospheric rearrangements arising therefrom.

As in the Atlantic and circum-Antarctic areas, the mid-Holocene transition is present in numerous sedimentary records and corresponds to a major atmospheric change. Thus, Markgraf et al. (1992) highlight the shift between two atmospheric circulation modes, resulting in the displacement of the southern Westerlies during the mid-Holocene following the strengthening of the south-east Pacific anticyclone ([Markgraf, 1993] and [Markgraf, 1998]; Jenny et al., 2003). The increase of insolation during this period would have increased the temperature gradient between the tropics and high latitudes, which resulted in an increase in sea ice around Antarctica (Nielsen et al., 2004). More recently, several investigations confirmed and clarified this pattern by the study of marine (Lamy et al., 2001, Chilean continental slope) and lacustrine cores (Gilli et al., 2005 Lago Cardiel, Argentina $49^{\circ} \mathrm{S}$ and Mayr et al., 2007 at Laguna Potrok Aike $\left.52^{\circ} \mathrm{S}\right)$. During the first part of the Holocene (7700 
4000 years BP), the Westerlies are located south of $41^{\circ} \mathrm{S}$. This position of southern Westerlies could be linked to the intensification or migration of the south-east Pacific anticyclone which deviates westerly winds to the south. In addition, this situation coincides with a shift to the south of the Antarctic Circumpolar Current (ACC) that reduced the advection of ACC-derived water masses at the core location. After 4000 years BP, the Westerlies migrated to the north to reach their current position. This is in accordance with several investigations conducted in a bog of Patagonia, Tierra del Fuego, that identified an increase in rainfall ([Pendall et al., 2001] and [Borromei et al., 2007]). Similarly, while the Early Holocene is characterised by glaciers smaller than present, the mid-Holocene transition is marked by periods of glacial expansion in Patagonia (Glasser et al., 2004) in connection with a period of very strong cooling, called the Neoglacial period.

\section{Holocene variability: ocean, atmosphere, solar interaction}

The structure of Holocene paleoclimatic records is comparable in Antarctica/South Atlantic, in the Tropics and in the North Atlantic area. The millennial variability of the last 10000 years can be divided into three periods, all with different forcing (Fig. 8).

\subsection{Solar activity imprint on the Early Holocene}

During the first part of the Holocene (10 000 to around 5000 years BP), congruent cyclicities in paleoclimate records and solar activity may indicate a casual relationship between the Sun and the Earth's climate (e.g. [Vonmoos et al., 2006], [Dergachev et al., 2007] and [Yin et al., 2007]), even though processes transmitting and amplifying the small energy changes associated with solar activity to the earth's surface are not well understood ([Van Geel et al., 1999] and [Beer et al., 2000]). The low sea ice cover is characteristic of this period of maximum summer insolation in the Northern Hemisphere (Fig. 8). Moreover, the hydrological cycle in the Northern Hemisphere is particularly perturbed by the massive melting of the last remnant ice from the Laurentide ice sheet. The formic acid in the Greenland ice core indirectly recorded the development of the biosphere, which perfectly follows the withdrawal of the Laurentide Ice Sheet ([Legrand and DeAngelis, 1995] and [Mayewski et al., 1981]). These freshwater contributions coupled with a change in marine topography (due to the rising sea level) have disrupted the activity of thermohaline circulation, preventing THC to oscillate in a cyclic manner. As a result, solar activity cyclicities are expressed in most paleoclimate records. One notable exception is the study of Irish bog oaks (Turney et al., 2005) which showed evidence of thermohaline circulation rather than evidence of solar forcing. Cross-spectral analysis between the Irish tree and ${ }^{14} \mathrm{C}$ production over the last 7500 years however demonstrated congruent and significant cyclicities at $\sim 500$ years and $\sim 285$ years, which are periods present in the solar activity. It is also worth noting that the cross-spectral analysis missed the Early Holocene when solar cycles are best expressed in paleorecords.

\subsection{A major climatic change during the mid-Holocene transition}

The mid-Holocene transition is probably the key period of the Holocene climate change, marked by a change in the frequencies (from solar to internal imprint), or even an abrupt and pronounced shift involving a threshold concept that is difficult to assess. Yet it is precisely at this time that the sea level stabilized (Fig. 8), meltwater flux became negligible and especially insolation reached a maximum level of variation (Fig. 8). There is statistically a greater probability of climate change under these conditions. Claussen et al. (1999) and Ganopolski 
et al. (1998) have validated this assumption with coupled models. If proxy changes are abrupt, they may have occurred during a period that can be estimated between 4000 and 6000 years $\mathrm{BP}$, a period of maximum variation of insolation. The problem of timing for this major climatic change probably does not highlight a problem of chronology or age scale but rather a direct link with the sensitivity of the system and the proxy taken into account. Thermohaline circulation, which attempts to stabilise its frequency during the Early Holocene, met optimal conditions during the mid-Holocene, giving rise to a gradual increase in the intensity of the internal imprint (Fig. 8).

\subsection{Solar and internal forcing during the Late Holocene}

The Late Holocene is marked by the stabilisation of new conditions with a THC firmly established, regulating the sea ice cover and, as a result, the atmospheric circulation that settles on the ocean frequencies.

There are however variations in the frequency allocated from internal forcing (Fig. 8). The Atlantic sector shows a period of around 1600 years \pm 200 years while Antarctica shows a slightly shorter period of $1300 \pm 50$ years (Fig. 7). Errors in dating models cannot explain these differences: 300 years per cycle, i.e. about 1800 years for the Holocene (Atlantic sector: 6 cycles $\times 1600$ period $=9600$ years; Antarctic sector: $6 \times 1300=7800$ years). The flow of ACC $(120 \mathrm{~Sv})$ is 10 times higher than the MOC $(14 \mathrm{~Sv})$. It is possible that the frequency of the MOC does not influence the ACC and that each fluctuates according to its own frequency. The origin of the Atlantic frequency is not clear, but "atmospheric water transport" (Broecker et al., 2001) or a "persistent internal salt oscillator" (McManus et al., 1999) has been proposed. The Antarctic frequency can be explained by "The Southern Ocean Flip-Flop" oscillator already suggested by Crosta et al. (2007). This process, based on an oscillation between two states of the ocean, with a strong stratification or strong convection through the intermediary of sea ice, appears to oscillate with a period of 1100 years (Drijfhout et al., 1996). This result, from a primitive equation ocean model, involves interaction with the NADW. However the frequencies of the two oceans are different and do not allow the interaction of the NADW. Independence of the two oceans is nevertheless likely, at least for the frequency content. Indeed, Pierce et al. (1995), showed that despite a shut down of the NADW, THC continues to oscillate but distinctively and differently. Rahmstorf and England (1997) estimate that the thermohaline circulation can generate up to $75 \%$ of the NADW flow. These results thus support the classic view of Atlantic deep circulation being predominantly thermohaline-driven rather than driven by the winds over the Southern Ocean (Rahmstorf and England, 1997). On the other hand, they believe that the formation of Antarctic Bottom Water depends intimately on winds over the Southern Ocean (Rintoul, 1998).

The combined results of this work could explain the Holocene pattern. Indeed, the pump of thermohaline circulation could be the North Atlantic area, since the disruption of the hydrological cycle by the freshwater input at the beginning of the Holocene affects the circulation around Antarctica. However, the frequencies may be different from one ocean to another (Pierce et al., 1995) since atmospheric circulation is essential to the formation of Antarctic Bottom Water, for example, while THC is sufficient to launch the pump of the NADW (Rahmstorf and England, 1997).

Internal forcing, which appears gradually during the Holocene and evolves to a stable state by the mid-Early Holocene, would appear to be oceanic but the frequency could be the result of an atmosphere/ocean coupling depending on sectors taken into account. Although THC 
forcing seems to explain the variability in the Atlantic, an ocean/atmosphere interaction is more likely for the Antarctic area in relation to the Westerlies, as well as the Pacific in relation to El Nino. Unfortunately there are not enough records available to check this assumption. This approach needs to be extended around the world in order to define the different frequencies that can interfere in the regions concerned.

\subsection{Holocene trend of methane}

The study of various records from the North Atlantic to the Antarctic oceans led us to propose a worldwide pattern of Holocene climate variability forced at the millennial time scale by solar activity during the Early Holocene and thermohaline circulation since 5000 years BP. We further used these results and interpretations to support a new hypothesis about the factors controlling Holocene variability of $\mathrm{CH}_{4}$ concentrations.

Understanding Holocene variability of greenhouse gases is a hot topic in the context of anthropic-induced global warming. According to Ruddiman (2007), non-natural $\mathrm{CH}_{4}$ increase would have started 5000 years ago, which is still under debate (e.g. [Broecker et al., 2001], [Ruddiman and Thomson, 2001], [Ruddiman, 2003a], [Ruddiman, 2003b], [Ruddiman, 2005], [Ruddiman, 2007], [Joos et al., 2004], [Schmidt et al., 2004] and [Masson-Delmotte et al., 2006]). The question is whether the Holocene evolution of $\mathrm{CH}_{4}$ concentrations is purely natural (northern Hemisphere humid zones) or if human activity (agriculture, stock farming) altered the natural evolution as it bears profound impact on paleoclimate interpretations.

During the Early Holocene, decreasing methane concentrations seems controlled by the climate of the low latitude in response to dropping summer northern insolation (Fig. 9). A major perturbation is observed at around 8200 years BP corresponding to a proglacial lake drainage which is an unusual event is not taken into account thereafter because do not correspond to a cyclic event. Investigation of the inter-hemispheric $\mathrm{CH}_{4}$ gradient demonstrated that boreal sources of methane tended to increase progressively at the expense of tropical sources until they reached the dominant contribution around 5500 years BP (Fig. 9) (Chappellaz et al., 1997). Such results are in agreement with other studies that indicated a period of massive peat growth in the boreal region (Chappellaz et al., 1997 and references therein). Methane concentrations should follow the insolation-based distribution of wetlands and the strong decoupling between greenhouse gases and northern summer insolation depicts the first human imprint ([Ruddiman, 2003a] and [Ruddiman, 2003b]). More specifically, important biomass burning and rice irrigation can explain the methane anomaly (Ruddiman, 2007). We however here propose a natural cause of methane concentration changes until 2800 years BP. The proposed hypothesis implies THC as the vector of the increase in the concentration of methane since the Mid-Holocene (Fig. 9). Our WA highlight that the MidHolocene climatic shift recorded worldwide is synchronous to the establishment of an oceanic signature, probably in relation to a sustainable salinity gradient pump of the thermohaline circulation. Well-established thermohaline circulation since 5000 years BP was more effective in providing latent heat and moisture to northern high latitudes, which contributed to the development of the wetlands evidenced in the Boreal zones. In this hypothesis, methane is decoupled from the sun's energy because the thermohaline circulation gradually counterbalanced and eventually offset the decrease in northern summer insolation.

Since 2500 years BP, methane concentrations increased drastically though the THC was not stronger (McManus et al., 2004). For this period, the inter-hemispheric gradient gives mixed information on the geographical origin of the sources (Chappellaz et al., 1997). The 
decoupling between $\mathrm{CH}_{4}$ concentrations and natural forcings as documented by our WA and other studies may indicate the first evidence of human impact on global climate at 2500 years BP rather than at 5000 years BP as estimated by Ruddiman (2007). Further investigations (modelling, paleoclimatic reconstructions,...) are necessary to better understand the physical and biogeochemical processes involved in the greenhouse gases dynamics and how these processes interacted with external and internal forcings during the Holocene.

\section{Conclusion}

Wavelet analysis of numerous records throughout the Atlantic in both hemispheres not only helped to assess Holocene climate variability by comparing distinct paleoclimatic records (i.e. marine, terrestrial or ice cores) around the world, but also to propose a worldwide pattern for the Holocene millennial modes of variability. The first part of the Holocene was characterised by frequencies typical of high solar activity (1000 years and 2500 years continuous throughout the Holocene). However, it was not possible to delineate the stable (i.e. stationary) imprint of any internal forcings (e.g. atmospheric and/or oceanic mechanisms) during this early part of Holocene. It was also shown that some global-influence climatic events (e.g. $8200 \mathrm{BP}$ ) could alter the variability of all paleoclimatic records over short time periods without any direct linkage to solar forcing. For instance, during the early phase of the Holocene, the erratic meltwater pulses along with a continuous sea level rise would prevent the density gradient in the North Atlantic and associated THC regime from getting stabilized. Around 5000 years BP, THC was finally stabilized for the second half of the Holocene. This mid-Holocene transition is the key period of the entire Holocene since many parameters influencing weather or climate changed abruptly: sea level decreased, the flow of meltwater became insignificant and insolation reached its maximum variation. The 1000 -year solar cycles disappeared in favour of a cyclical internal (ocean) forcing. It is therefore possible to complement and extend the scheme developed for the North Atlantic. The sea ice cover in Antarctica can be linked to climate variability in the Northern Hemisphere that appears to regulate the Atlantic and even global climate. Models have made it possible to propose a hypothesis concerning the origin of internal forcing during Late Holocene. Although for Atlantic forcing, the THC seems to be sufficient for the stabilisation of the NADW regime, it seems that an ocean/atmosphere coupling is more likely for the Southern Ocean. For the Pacific (South America area), the same Holocene pattern would appear to be present but not enough records are available to confirm this. The mid-Holocene transition also shows a decoupling between methane concentrations and northern summer insolation, this could be a result of THC-induced moisture transport to the boreal zones. The real increase in $\mathrm{CH}_{4}$ concentrations occurred at 2500 years BP as a result of human activity.

\section{Acknowledgements}

We acknowledge Basile Deflorian, John Andrews, Matthias Moros, Bjørg Risebrobakken, Martine DeAngelis, Jerôme Chappellaz, Laetitia Loulergue, Jean-Marc Barnola, Dominique Raynaud, Emmanuel LeMeur, Valérie Masson-Delmotte for their valuable insight, availability and/or for having shared their data. This work is supported by the ANR project: "Intégration des contraintes Paléoclimatiques pour réduire les Incertitudes sur l'évolution du Climat pendant les périodes Chaudes" - PICC (ANR-05-BLAN-0312-02). We thank Chris Turney and Simon Nielsen for their fruitful review.

\section{References}


Alley et al., 1997 R.B. Alley, P.A. Mayewski, T. Sower, M. Stuiver, K.C. Taylor and P.U. Clark, Holocene climate instability: a prominent, widespread event 8200 yrs ago, Geology 25 (1997), pp. 483-486.

Andrews et al., 2003 J.T. Andrews, J. Hardardottir, J.S. Stoner, M.E. Mann, G.B.

Kristjansdottir and N. Koc, Decadal to millennial-scale periodicities in North Iceland shelf sediments over the last $12000 \mathrm{cal}$ yr: long-term North Atlantic oceanographic variability and solar forcing, Earth and Planetary Science Letters 210 (2003), pp. 453-465.

Armand et al., 2005 L. Armand, X. Crosta, O. Romero and J.J. Pichon, The biogeography of major taxa in southern ocean sediments. 1. Sea ice related species, Palaeogeography Palaeoclimatology Palaeoecology 223 (2005), pp. 93-126.

Arz et al., 2001 H.W. Arz, S. Gerhardt, J. Pätzdold and U. Röhl, Millennial-scale changes of surface and deep-flow in the western tropical Atlantic linked to Northern Hemisphere highlatitude climate during the Holocene, Geology 29 (3) (2001), pp. 239-242.

Beer et al., 2000 J. Beer, W. Mende and R. Stellmacher, The role of the sun in climate forcing, Quaternary Science Reviews 19 (2000), pp. 403-415.

Berkman et al., 1998 P.A. Berkman, J.T. Andrews, S. Björck, E.A. Colhoun, S.D. Emslie, I.D. Goodwin, B.L. Hall, C.P. Hart, K. Hirakawa, A. Iganashi, O. Ingolfsson, J. LopezMartinez, W. Berry Lyons, M.C.G. Mabin, P.G. Quilty, M. Tavioni and Y. Yoshida, CircumAntarctic coastal environmental shifts during the Late Quaternary reflected by emerged marine deposits, Antarctic Science 10 (1998), pp. 345-362.

Bianchi and McCave, 1999 G.G. Bianchi and N. McCave, Holocene periodicity in North Atlantic climate and deep-ocean flow south of Iceland, Nature 397 (1999), pp. 515-517.

Björck et al., 1996 S. Björck, S. Olsson, C. Ellis-Evans, H. Håkansson, O. Humlum and J.M. de Lirio, Late Holocene palaeoclimate records from lake sediments on James Ross Island, Antarctica, Palaeogeography Palaeoclimatology Palaeoecology 121 (1996), pp. 195-220.

Blunier et al., 1995 T. Blunier, J. Chappellaz, J. Schwander, B. Stauffer and D. Raynaud, Variation in atmospheric methane concentration during the Holocene epoch, Nature 374 (1995), pp. 46-49.

Bond et al., 2001 G. Bond, B. Kromer, J. Beer, R. Muscheler, M. Evans, W. Showers, S. Hoffmann, R. Lotti-Bond, I. Hajdas and G. Bonani, Persistent solar influence on North Atlantic climate during the Holocene, Science 294 (2001), pp. 2130-2136.

Borromei et al., 2007 A.M. Borromei, A. Coronato, M. Quattrocchio, J. Rabassa, S. Grill and C. Roig, Late Pleistocene-Holocene environments in Valle Carbajal, Tierra del Fuego, Argentina, Journal of South American Earth Sciences 23 (2007), pp. 321-335

Broecker et al., 2001 W. Broecker, S. Sutherland and T.H. Peng, A possible 20th-century slowdown of Southern ocean deep Water formation, Science 286 (2001), pp. 1132-1135. 
Cai and Baines, 2001 W. Cai and P.G. Baines, Forcing of the Antarctic Circumpolar Wave by El Niño-Southern Oscillation teleconnections, Journal of Geophysical Research 106 (C5) (2001), pp. 9019-9038.

Chapman and Shackleton, 2000 M.R. Chapman and N. Shackleton, Evidence of 550-year and 1500-year cyclicities in North Atlantic circulation pattern during the Holocene, The Holocene 10 (3) (2000), pp. 287-291.

Chappellaz et al., 1997 J. Chappellaz, T. Blunier, S. Kints, A. Dallenbach, J.-M. Barnola, J. Schwander, D. Raynaud and B. Stauffer, Changes in the $\mathrm{CH}_{4}$ gradient between Greenland and Antarctica during the Holocene, Journal of Geophysical Research 102 (1997), pp. 1598715997.

Ciais et al., 1992 P. Ciais, J.R. Petit, J. Jouzel, C. Lorius, N.I. Barkov, V. Lipenkov and V. Nicolaiev, Evidence for an early Holocene climatic optimum in the Antarctic deep ice-core record, Climate Dynamics 6 (1992), pp. 169-177.

Clapperton and Sudgen, 1988 C. Clapperton and D. Sudgen, Holocene glacier fluctuations in South America and Antarctica, Quaternary Science Reviews 7 (1988), pp. 185-198.

Claussen et al., 1999 M. Claussen, C. Kubatzki, V. Brovkin, A. Ganopolski, P. Hoelzmann and H.J. Pachur, Simulation of an abrupt change in Saharan vegetation in the mid-Holocene, Geophysical Research Letters 14 (1999), pp. 2037-2040.

Crosta et al., 2007 X. Crosta, M. Debret, D. Denis, M.A. Courty and O. Ther, Holocene longand short-term climate changes off Adelie Land, East Antarctica, Geochemistry Geophysics Geosystems 8 (2007), p. Q1 1009

Crosta et al., 2005 X. Crosta, O. Romero, L. Armand and J.J. Pichon, The biogeography of major diatom taxa in Southern Ocean sediments. 2. Open Ocean related species, Palaeogeography Palaeoclimatology Palaeoecology 223 (2005), pp. 66-92.

Debret et al., 2007 M. Debret, V. Bout-Roumazeilles, F. Grousset, M. Desmet, J.F. McManus, N. Massei, D. Sebag, J.R. Petit, Y. Copard and A. Trentesaux, The origin of the 1500-year climate cycles in Holocene North-Atlantic records, Climate of the Past 3 (2007), pp. 569-575.

deMenocal et al., 2000a P. deMenocal, J. Ortiz, T. Guilderson and M. Sarnthein, Coherent high- and low-latitude climate variability during the Holocene Warm Period, Science 288 (2000), pp. 2198-2202.

deMenocal et al., 2000b P. deMenocal, J. Ortiz, T. Guilderson, J. Adkins, M. Sarnthein, L. Baker and M. Yarusinsky, Abrupt onset and termination of the African humid period: rapid climate response to gradual insolation forcing, Quaternary Science Reviews 19 (2000), pp. 347-361.

Dergachev et al., 2007 V.A. Dergachev, O.M. Raspopov, F. Damblon, H. Jungner and G.I. Zaitseva, Natural climate variability during the Holocene, Radiocarbon 49 (2) (2007), pp. 837-854. 
Domack et al., 2001 E. Domack, A. Leventer, R. Dunbar, F. Taylor, S. Brachfeld, C. Sjunneskog and ODP Leg 178 Scientific Party, Chronology of the Palmer Deep site, Antarctic Peninsula: a Holocene palaeoenvironmental reference for the circum-Antarctic, The Holocene 11 (2001), pp. 1-9.

Drijfhout et al., 1996 S. Drijfhout, C. Heinze, M. Latif and E. Maeir-Reimer, Mean circulation and internal variability in an ocean primitive equation model, Journal of Physical Oceanography 26 (1996), pp. 559-580.

Ekström et al., 2006 G. Ekström, M. Nettles and V.C. Tsai, Seasonality and increasing frequency of Greenland Glacial earthquakes, Science 311 (2006), pp. 1756-1758.

EPICA Community Members, 2006 EPICA Community Members, Eight glacial cycles from an Antarctic ice core, Nature 429 (6992) (2006), pp. 623-628.

Ganopolski et al., 1998 A. Ganopolski, C. Kubatzki, M. Claussen, V. Brovkin and V. Petoukhov, The influence of vegetation-atmosphere-ocean interaction on climate during the mid-Holocene, Science 220 (1998), pp. 1916-1919.

Gilli et al., 2005 A. Gilli, D. Ariztegui, F. Anselmetti, J.A. McKenzie, V. Markgraf, I. Hajdas and R. McCulloch, Mid-Holocene strengthening of the southern westerlies in South America - sedimentological evidences from Lago Cardiel, Argentina (491S), Global and Planetary Change 49 (2005), pp. 75-93.

Giraudeau et al., 2000 J. Giraudeau, M. Cremer, S. Manthè, L. Labeyrie and G. Bond, Coccolith evidence for instabilities in surface circulation south of Iceland during Holocene times, Earth and Planetary Science Letters 179 (2000), pp. 257-268.

Glasser et al., 2004 N.F. Glasser, S. Harrison, V. Winchester and M. Aniya, Late Pleistocene and Holocene palaeoclimate and glacier fluctuations in Patagonia, Global and Planetary Change 43 (2004), pp. 79-101.

Hammer et al., 1985 C.U. Hammer, H.B. Clausen, W. Dansgaard, A. Neftel, P. Kristinsdottir and E. Johnson, Continuous impurity analysis along the Dye 3 deep core. In: C.C. Langway Jr., H. Oeschger and H. Dansgaard, Editors, Greenland Ice Core, American Geophysical Union, Washington, DC (1985), pp. 90-94.

Hammer et al. (1994) C.U. Hammer, H.B. Claussen and C.C. Langway Jr., Electrical conductivity method (ECM) stratigraphic dating of the Byrd station ice core, Antarctica, Annals of Glaciology 20 (1994), pp. 115-120.

Hodell et al., 2001 D.A. Hodell, S.L. Kanfoush, A. Shemesh, X. Crosta, C.D. Charles and T.P. Guilderson, Abrupt cooling of Antarctic surface waters and sea ice expansion in the South Atlantic sector of the Southern Ocean at 5000 cal yr B.P., Quaternary Research 56 (2001), pp. 191-198.

Hoffmann, 2003 G. Hoffmann, Taking the pulse of the tropical water cycle, Science 301 (2003), pp. 776-777. 
Hoffmann et al., 2003 G. Hoffmann, E. Ramirez, J.D. Taupin, B. Francou, P. Ribstein, R. Delmas, H. Dürr, R. Gallaire, J. Simoes, U. Schotterer, M. Stievenard and M. Werner, Coherent isotope history of Andean ice cores over the last century, Geophysical Research Letters 30 (4) (2003), p. 1179

Ingolfsson et al., 1998 O. Ingolfsson, C. Hjort, P.A. Berkman, S. Bjorck, E. Colhoun, I.D. Goodwin, B. Hall, K. Hirakawa, M. Melles, P. Moller and M.L. Prentice, Antarctic glacial history since the Last Glacial Maximum: an overview of the record on land, Antarctic Science 10 (1998), pp. 326-344.

Jackson et al., 2005 M.G. Jackson, N. Oskarson, R.G. Trønnes, J.F. McManus, D. Oppo, K. Grönveld, S.R. Hart and J.P. Sachs, Holocene loess deposition in Iceland: evidence for millennial-scale atmosphere-ocean coupling in the North-Atlantic, Geology 33 (2005), pp. 509-512.

Jennings et al. (2002) A.E. Jennings, K.L. Knudsen, M. Hald, C.V. Hansen and J.T. Andrews, A mid-Holocene shift in Arctic sea-ice variability on the East Greenland shelf, The Holocene 12 (1) (2002), pp. 49-58.

Jenny et al., 2003 B. Jenny, D. Wilhelm and B.L. Valero-Garcés, The southern westerlies in Central Chile: Holocene precipitation estimates based on a water balance model for Laguna Aculeo (331500S), Climate Dynamics 20 (2003), pp. 269-280.

Joos et al., 2004 F. Joos, S. Gerber, I.C. Prentice, B.L. Otto-Bliesner and P.J. Valdes, Transient simulations of Holocene atmospheric carbon dioxide and terrestrial carbon since the Last Glacial Maximum, Global Biogeochemical Cycles 18 (2004)

Joughin, 2006 I. Joughin, Greenland rumbles louder as glaciers accelerate, Science 311 (2006), pp. 1719-1720.

Joughin et al., 2004 I. Joughin, W. Abdalati and M. Fahnestock, Large fluctuations in speed on Greenland's Jakobshavn Isbræ glacier, Nature 432 (2004), p. 608.

Kuhlmann et al., 2004 H. Kuhlmann, H. Meggers, T. Freudenthal and G. Wefer, The transition of the monsoonal and the N Atlantic climate system off NW Africa during the Holocene, Geophysical Research Letters 31 (2004), p. L22204 10.1029/2004GL021267.

Lamy et al., 2001 F. Lamy, D. Hebbeln, U. Röhl and G. Wefer, Holocene rainfall variability in southern Chile: a marine record of latitudinal shifts of the Southern Westerlies, Earth and Planetary Science Letters 185 (2001), pp. 369-382.

Legrand and DeAngelis, 1995 M. Legrand and M. DeAngelis, Origins and variations of light carboxylic acids in polar precipitation, Journal of Geophysical Research 100 (D1) (1995), pp. $1445-1462$.

Markgraf, 1993 V. Markgraf, Climatic history of Central and South America since 18,000 years B.P.: comparison of pollen records and model simulations. In: H.E. Wright, J.E. Kutzbach, T. Webb III, W.F. Ruddiman, F.A. Street-Perrott and P.J. Bartlein, Editors, Global Climates Since the Last Glacial Maximum, University of Minnesota Press, Minneapolis, London (1993), pp. 357-385. 
Markgraf, 1998 V. Markgraf, Past climates of South America. In: J.E. Hobbs, J.A. Lindesay and H.A. Bridgman, Editors, Climates of the Southern Continents: Present, Past and Future, John Wiley and Sons Ltd. (1998), pp. 249-264.

Markgraf et al., 1992 V. Markgraf, J.R. Dodson, P.A. Kershaw, M. McGlone and N. Nicholls, Evolution of Late Pleistocene and Holocene climates in circum South Pacific land areas, Climate Dynamics 6 (1992), pp. 193-211.

Masson-Delmotte et al., 2006 V. Masson-Delmotte, G. Dreyfus, P. Braconnot, S. Johnsen, J. Jouzel, M. Kageyama, A. Landais, M.F. Loutre, J. Nouet, F. Parrenin, D. Raynaud, B. Stenni and E. Tuenter, Past temperature reconstructions from deep ice cores: relevance for future climate change, Climate of the Past 2 (2006), pp. 145-165.

Mayewski et al., 1981 P.A. Mayewski, G.H. Denton and T.J. Hughes, The last Wisconsin ice sheets in North America. In: G.H. Dentonand and T.J. Hughes, Editors, The Last Great Ice Sheets, Wiley, New York (1981), pp. 67-178.

Mayr et al., 2007 C. Mayr, M. Wille, T. Haberzettl, M. Fey, S. Janssen, A. Lücke, C. Ohlendorf, G. Oliva, F. Schäbitz, G.H. Schleser and B. Zolitschka, Holocene variability of the Southern Hemisphere westerlies in Argentinean Patagonia (52 $\left.{ }^{\circ} \mathrm{S}\right)$, Quaternary Science Reviews 26 (2007), pp. 579-584.

McDermott et al., 1998 F. McDermott, D.P. Mattey and C. Chris Hawkesworth, Centennialscale Holocene climate variability revealed by a high-resolution speleothem $\mathrm{d}^{18} \mathrm{O}$ Record from SW Ireland, Science 294 (1998), pp. 1328-1331.

McDermott et al., 2005 F. McDermott, D.P. Mattey and C. Hawkesworth, Correction to 'Centennial-scale Holocene climate variability revealed by a high-resolution speleothem $\mathrm{d}^{18} \mathrm{O}$ record from SW Ireland', Science 309 (2005), p. 1816.

McManus et al. (1999) J.F. McManus, W.D. Oppo and J.L. Cullen, A 0.5-millionyear record of millennial-scale climate variability in the North Atlantic, Science 283 (1999), pp. 971-974.

McManus et al., 2004 J.F. McManus, R. François, J.M. Gherardi, L.D. Keigwin and S. Brown-Leger, Collapse and rapid resumption of Atlantic meridional circulation linked to deglacial climate changes, Nature 428 (2004), pp. 834-837.

Moros et al., 2004 M. Moros, K. Emeis, B. Risebrobakken, I. Snowball, A. Kuijpers, J. McManus and E. Jansen, Sea surface temperatures and ice rafting in the Holocene North Atlantic: climate influences on northern Europe and Greenland, Quaternary Science Reviews 23 (2004), pp. 2113-2126.

Moy et al., 2002 C.M. Moy, G.O. Seltzer, D.T. Rodbell and D.M. Anderson, Variability of El Ninõ Southern oscillation activity at millennial timescales during the Holocene epoch, Nature 420 (2002), pp. 162-165.

Nielsen et al., 2004 S.H.H. Nielsen, N. Koç and X. Crosta, Holocene climate in the Atlantic sector of the Southern Ocean: controlled by insolation or oceanic circulation?, Geology 32 (4) (2004), pp. 317-320 
Noon et al., 2003 P.E. Noon, M.J. Leng and V.J. Jones, Oxygen-isotope (d18O) evidence of Holocene hydrological changes at Signy Island, maritime Antarctica, The Holocene 13 (2) (2003), pp. 251-263.

O'Brien et al., 1995 S.R. O'Brien, P.A. Mayewski, L.D. Meeker, D.A. Meese, M.S. Twickler and S.L. Whitlow, Complexity of Holocene climate as reconstructed from a Greenland ice core, Science 270 (1995), pp. 1962-1964.

Pendall et al., 2001 E. Pendall, V. Markgraf, J.W. White and M. Dreier, Multiproxy record of Late Pleistocene-Holocene climate and vegetation changes from a peat bog in Patagonia, Quaternary Research 55 (2001), pp. 168-178.

Pierce et al., 1995 D.W. Pierce, T.P. Barnett and U. Mikolajewicz, Competing role of heat and freshwater flux in forcing thermohaline oscillations, Journal of Physical Oceanography 25 (1995), pp. 2046-2064.

Rahmstorf, 2002 S. Rahmstorf, Ocean circulation and climate during the past 120,000 years, Nature 419 (2002), pp. 207-214.

Rahmstorf and England, 1997 S. Rahmstorf and M.H. England, Sensitivity of ventilation rates and radiocarbon uptake to subgrid-scale mixing in ocean models, Journal of Physical Oceanography 29 (11) (1997), pp. 2802-2828.

Rignot and Kanagaratnam., 2006 E. Rignott and P. Kanagaratnam, Changes in the velocity structure of the Greenland ice sheet, Science 311 (2006), pp. 986-989.

Rintoul, 1998 S.R. Rintoul, On the origin and influence of Adélie land bottom water. In: S.S. Jacob, Editor, Ocean, Ice and Atmosphere: Interactions at the Antarctic Continental Margin vol. 75, American Geophysical Union, Washington, DC (1998), pp. 151-171.

Risebrobakken et al., 2003 B. Risebrobakken, E. Jansen, C. Andersson, E. Mjelde and K. Hevroy, A high-resolution study of Holocene paleoclimatic and paleoceanographic changes in the Nordic Seas, Paleoceanography 18 (2003), pp. 1017-1031.

Rodbell et al., 1999 D.T. Rodbell, G.O. Seltzer, D.M. Anderson, M.B. Abbott, D.B. Enfield and J.H. Newman, A 15,000-year record of El Nino-driven alluviation in southwestern Ecuador, Science 283 (1999), pp. 516-520.

Robertson and Tiedje, 1988 G.P. Robertson and J.M. Tiedje, Deforestation alters denitrification in a lowland tropical rain forest, Nature 336 (1988), pp. 756-759.

Ruddiman and Thomson, 2001 W.F. Ruddiman and J.S. Thomson, The case for human causes of increased atmospheric $\mathrm{CH}_{4}$ over the last 5000 years, Quaternary Science Reviews 20 (2001), p. 1769.

Ruddiman, 2003a W.F. Ruddiman, Orbital insolation, ice volume and greenhouse gases, Quaternary Science Reviews 22 (2003), pp. 1597-1629.

Ruddiman, 2003b W.F. Ruddiman, The anthropogenic greenhouse era began thousands of years ago, Climatic Change 61 (2003), pp. 261-293. 
Ruddiman et al., 2008 W.F. Ruddiman, Z. Guo, X. Zhou, H. Wu and Y. Yu, Early rice farming and anomalous methane trends, Quaternary Science Reviews 27 (2008), pp. 12911295.

Ruddiman, 2005 W.F. Ruddiman, Cold climate during the closest stage 11 analog to recent millennia, Quaternary Science Reviews 24 (2005), pp. 1111-1121.

Ruddiman, 2007 W.F. Ruddiman, The early anthropogenic hypothesis: challenges and responses, Review of Geophysics 45 (2007), pp. 1-37.

Salvi et al., 2004 C. Salvi, G. Salvi, B. Stenni and A. Brambati, Palaeoproductivity in the Ross Sea, Antarctica, during the last $15 \mathrm{kyr}$ BP and its link with ice-core temperature, Annals of Glaciology 39 (1) (2004), pp. 445-451.

Schmidt et al., 2004 G.A. Schmidt, D.T. Shindel and S. Harder, A note on the relationship between ice core methane concentrations and insolation, Geophysical Research Letters 31 (2004), p. L23206

Simmonds and Jacka, 1995 I. Simmonds and T.H. Jacka, Relationship between the interannual variability of Antarctic sea-ice and the Southern Oscillation index, Journal of Climate 8 (1995), pp. 637-647.

Solanki et al., 2004 S.K. Solanki, I.G. Usoskin, B. Kromer, M. Schüssler and J. Beer, Unusual activity of the Sun during recent decades compared to the previous 11,000 years, Nature 431 (2004), pp. 1084-1087.

Steig et al., 1998 E.J. Steig, C.P. Hart, J.W.C. White, W.L. Cunningham, M.D. Davis and E.S. Saltzman, Changes in climate, ocean and ice sheet conditions in the Ross Embayment, Antarctica, at 6 ka, Annals of Glaciology 27 (1998), pp. 305-310.

Talbot et al., 1988 R.W. Talbot, M.O. Andreae, T.W. Andreae and R.C. Harriss, Regional aerosol chemistry of the Amazon Basin during the dry season, Journal of Geophysical Research 93 (1988), pp. 1499-1508.

Thompson et al., 1995 L.G. Thompson, E. Mosley-Thompson, M.E. Davis, P.N. Lin, K.A. Henderson, J. Cole-Dai, J.F. Bolzan and K.B. Liu, Late Glacial Stage and Holocene tropical ice core records from Huascaran, Peru, Science 269 (1995), pp. 46-50.

Thompson et al., 1998 L.G. Thompson, M.E. Davis, E. Mosley-Thompson, T.A. Sowers, K.A. Henderson, V.S. Zagorodnov, P.N. Lin, V.N. Mikhalenko, R.K. Campen, J.F. Bolzan and J. Cole-Dai, A 25,000 year tropical climate history from Bolivian ice cores, Science 282 (1998), pp. 1858-1864.

Thompson et al., 2000 L.G. Thompson, E. Mosley-Thompson and K.A. Henderson, Ice-core palaeoclimate records in tropical South America since the Last Glacial Maximum, Journal of Quaternary Sciences 15 (2000), pp. 377-394.

Torrence and Compo, 1998 C. Torrence and G.P. Compo, A practical guide to wavelet analysis, Bulletin of the American Meteorological Society 79 (1998), pp. 61-78. 
Turney et al., 2005 C. Turney, M. Baillie, S. Clemens, D. Brown, J. Palmer, J. Pilcher, P. Reimer and H.H. Leuschner, Testing solar forcing of pervasive Holocene climate cycles, Journal of Quaternary Sciences 20 (2005), pp. 511-518.

Van Geel et al., 1999 B. Van Geel, O.M. Raspopov, H. Rensen, J. van der plicht, V.A. Dergachev and H.A.J. Meijers, The role of solar forcing upon climate change, Quaternary Science Reviews 18 (1999), pp. 331-338.

Vonmoos et al., 2006 M. Vonmoos, J. Beer and R. Muscheler, Large variations in Holocene solar activity - constraints from ${ }^{10} \mathrm{Be}$ in the GRIP ice core, Journal of Geophysical Research 111 (2006), p. A10105

Witt and Schumann, 2005 A. Witt and A.Y. Schumann, Holocene climate variability on millennial scales recorded in Greenland ice cores, Nonlinear Processes in Geophysics 12 (2005), pp. 345-352.

Yin et al., 2007 ZhiQiang Yin, LiHua Ma, YanBen Han and YongGang Han, Long-term variations of solar activity, Chinese Science Bulletin 52 (20) (2007), pp. 2737-2741. 


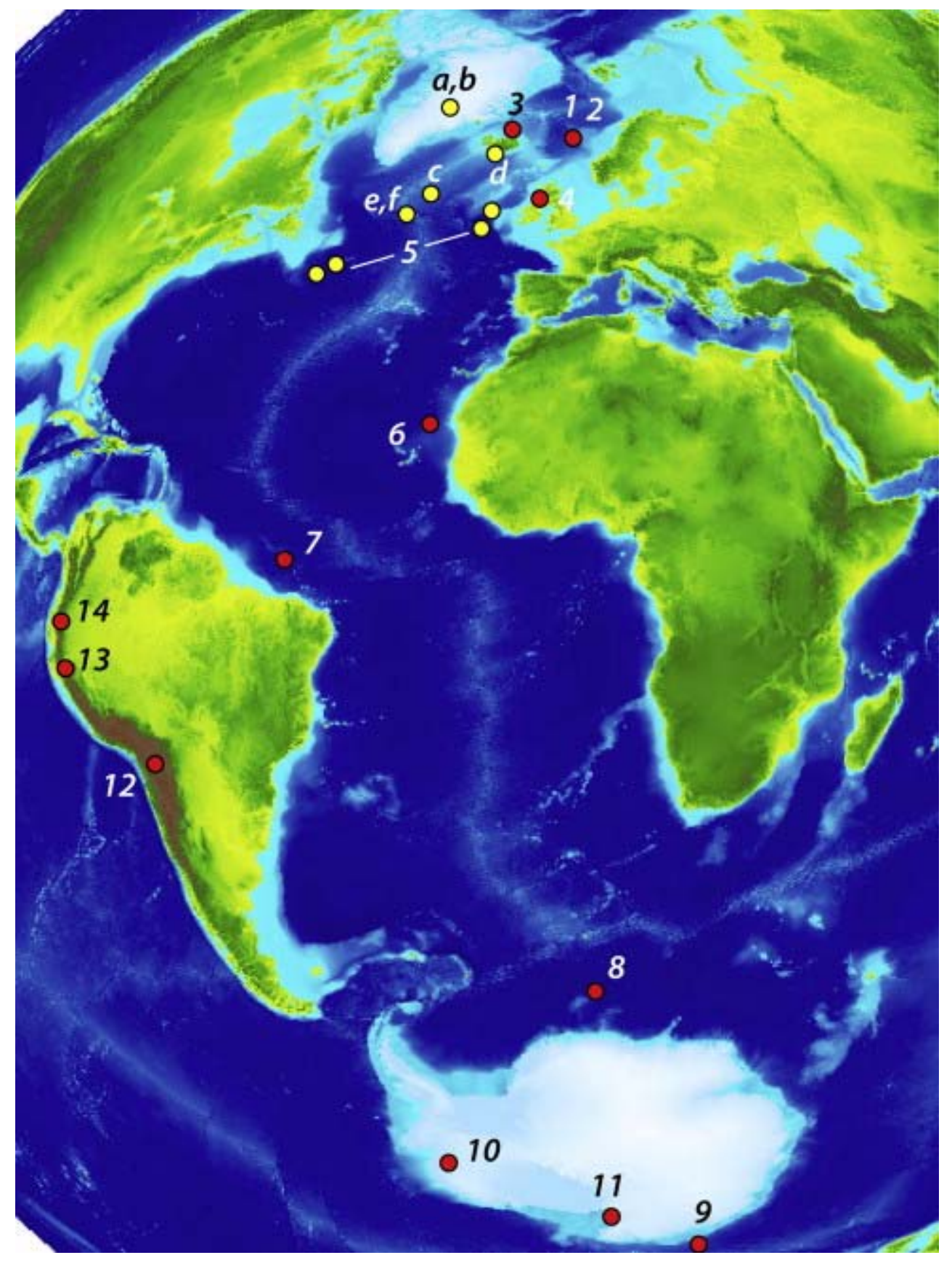

Fig. 1. Map of the core sites in the Atlantic ocean, South America and Antarctica. Yellow points represent cores for which data was already published in Debret et al. (2007):

(a) O'Brien et al., 1995, b) Vonmoos et al., 2006, c) Giraudeau et al., 2000, d) Jackson et al., 2005, e) Bianchi and McCave, 1999. The red points represent new data: 1) Risebrobakken et al., 2003, 2) Moros et al., 2004, 3) Andrews et al., 2003, 4) McDermott et al., 1998, 5) Bond et al., 2001, 6) [deMenocal et al., 2000a] and [deMenocal et al., 2000b], 7) Arz et al., 2001, 8) Nielsen et al., 2004, 9) Crosta et al., 2007, 10) Hammer et al., 1985, 11) Steig et al., 1998, 12) Thompson et al., 2000, 13) Thompson et al., 2000, 14) Moy et al., 2002. 


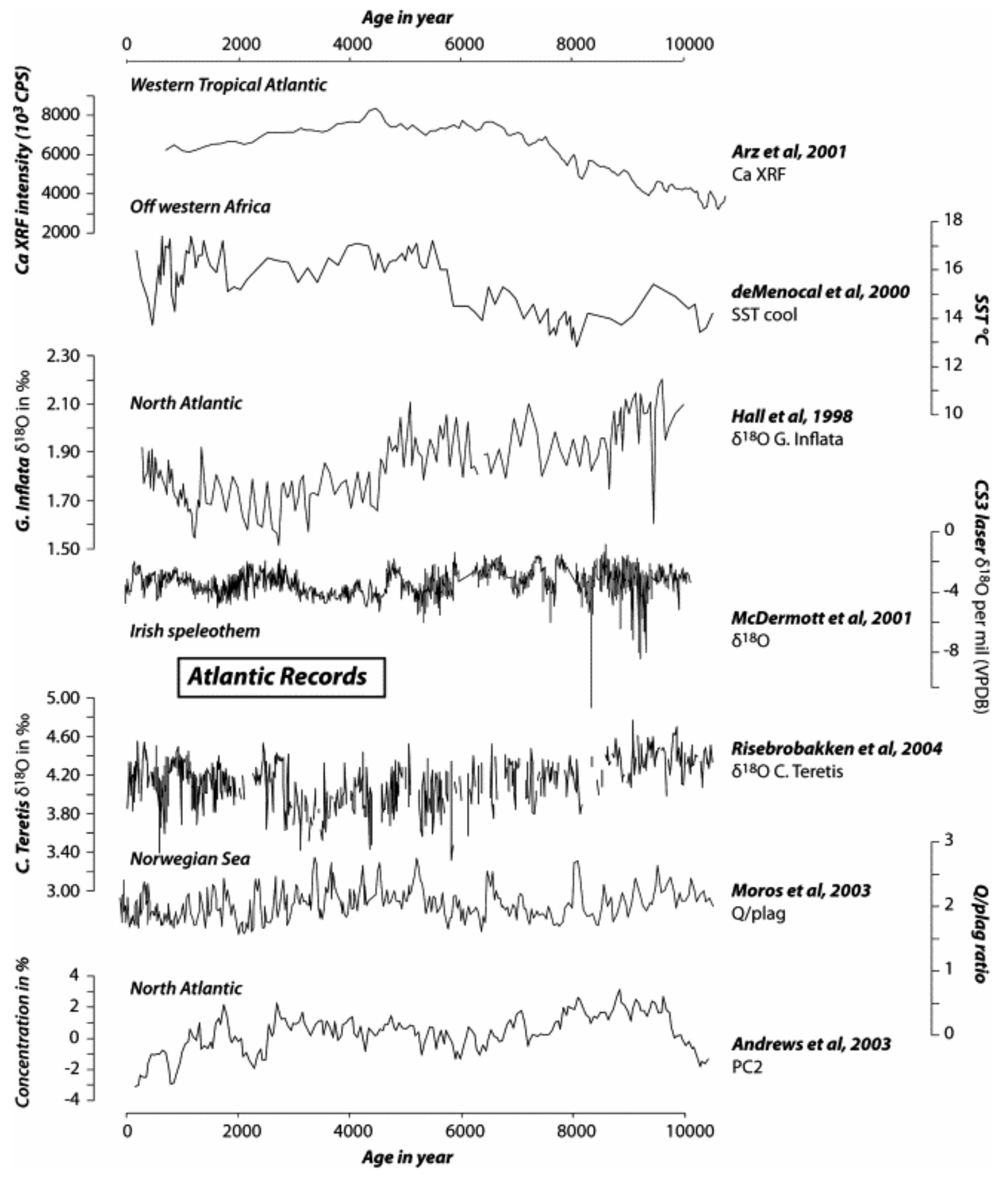

Fig. 2. Raw records from North Atlantic area published and used for this study. 


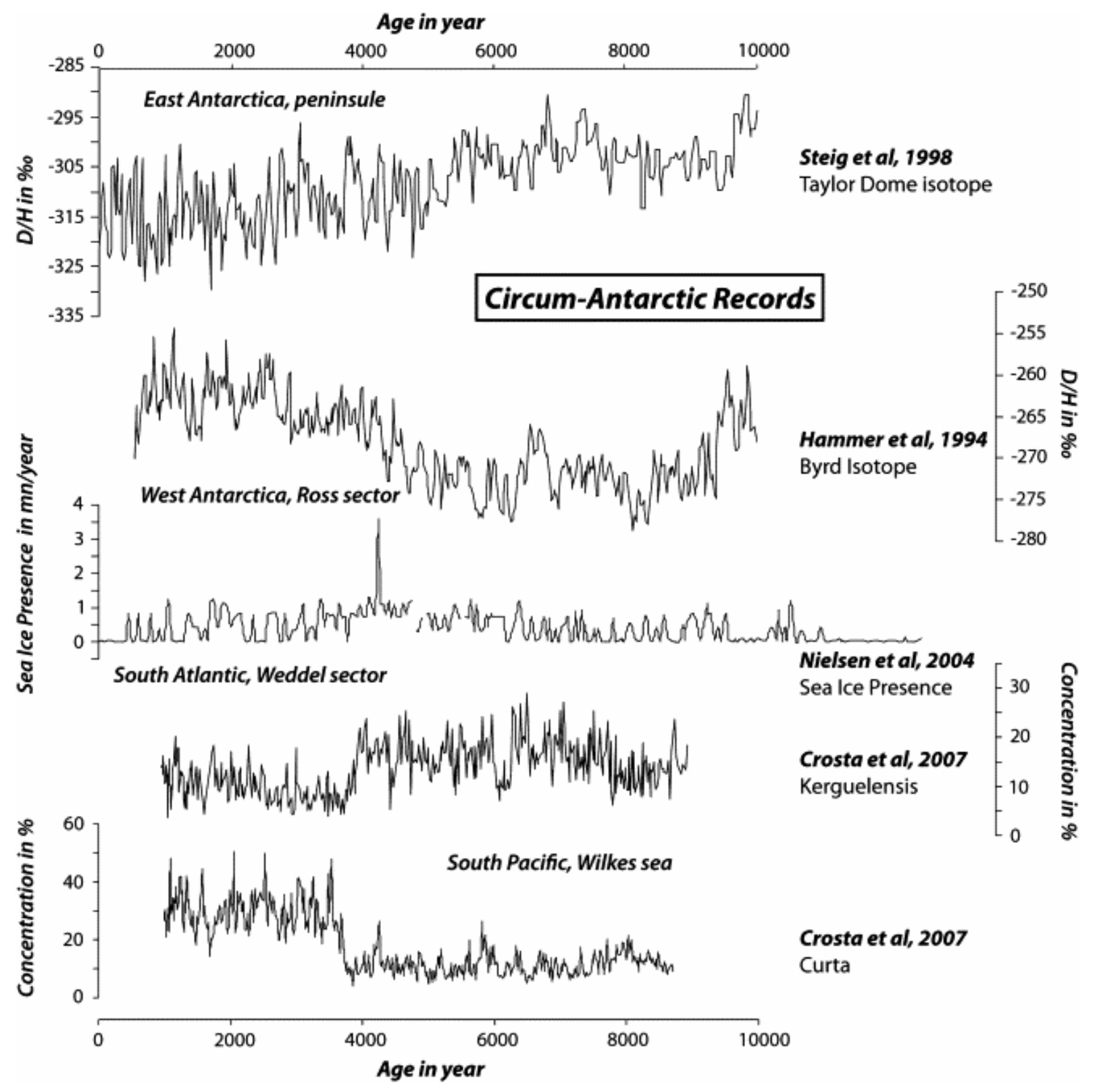

Fig. 3. Raw records from circum-Antarctic area published and used for this study. 

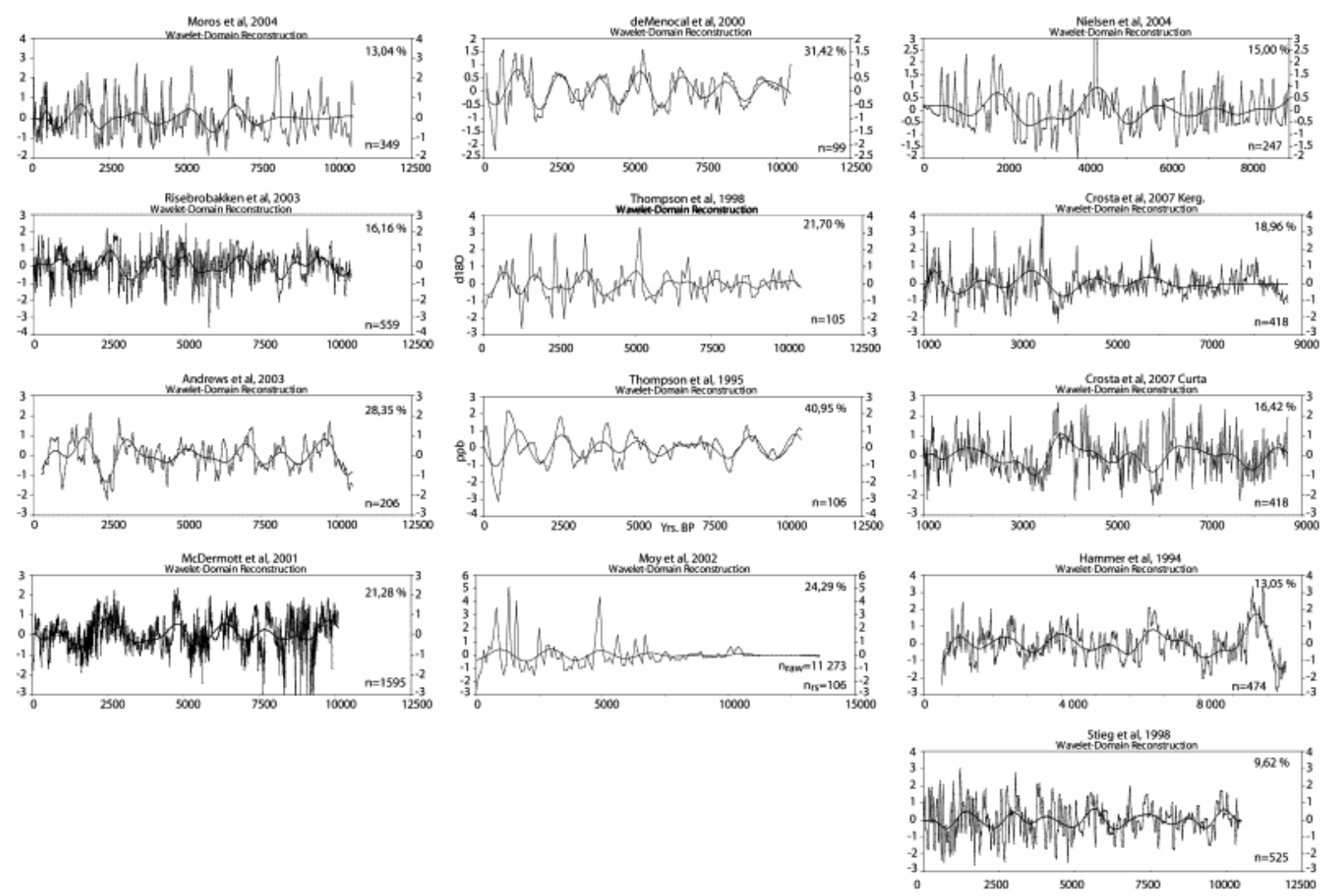

Fig. 4. Wavelet reconstruction of millennial scale periodicities. The percentage indicates the $\%$ of signal explained by wavelets reconstruction for the wavelength between 900 and 2800 years.
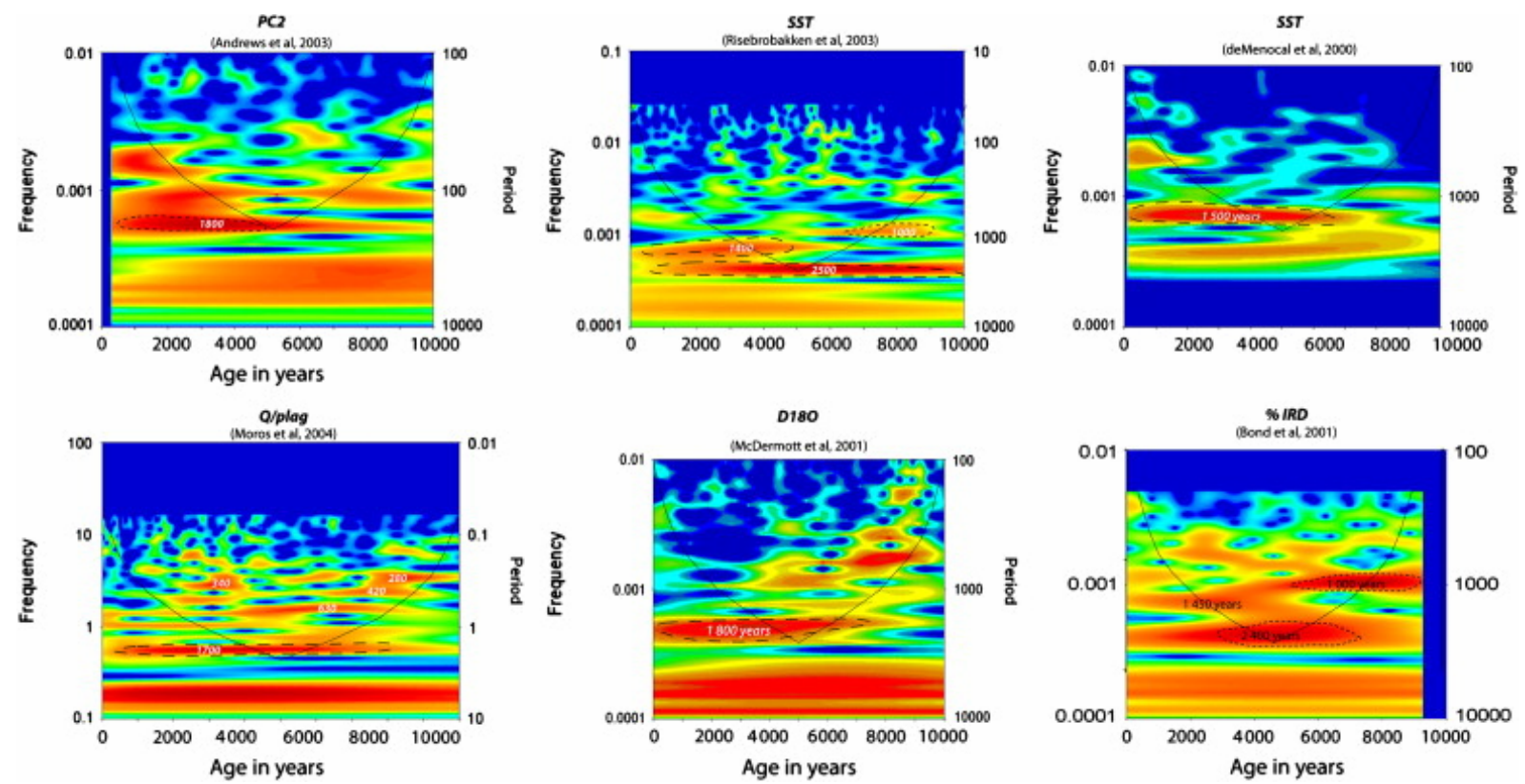
Fig. 5. Wavelet analyses for North Atlantic area. Occurrence of the periods (labelled) with respect to the time is given by the bright yellow-red colours. Black line corresponds to cone of influence. Horizontal band corresponding to periodicity higher than 3000 years is not meaningful. The confidence levels are indicated with the dot line: the fine one is $50 \%$ the larger is more than $95 \%$.
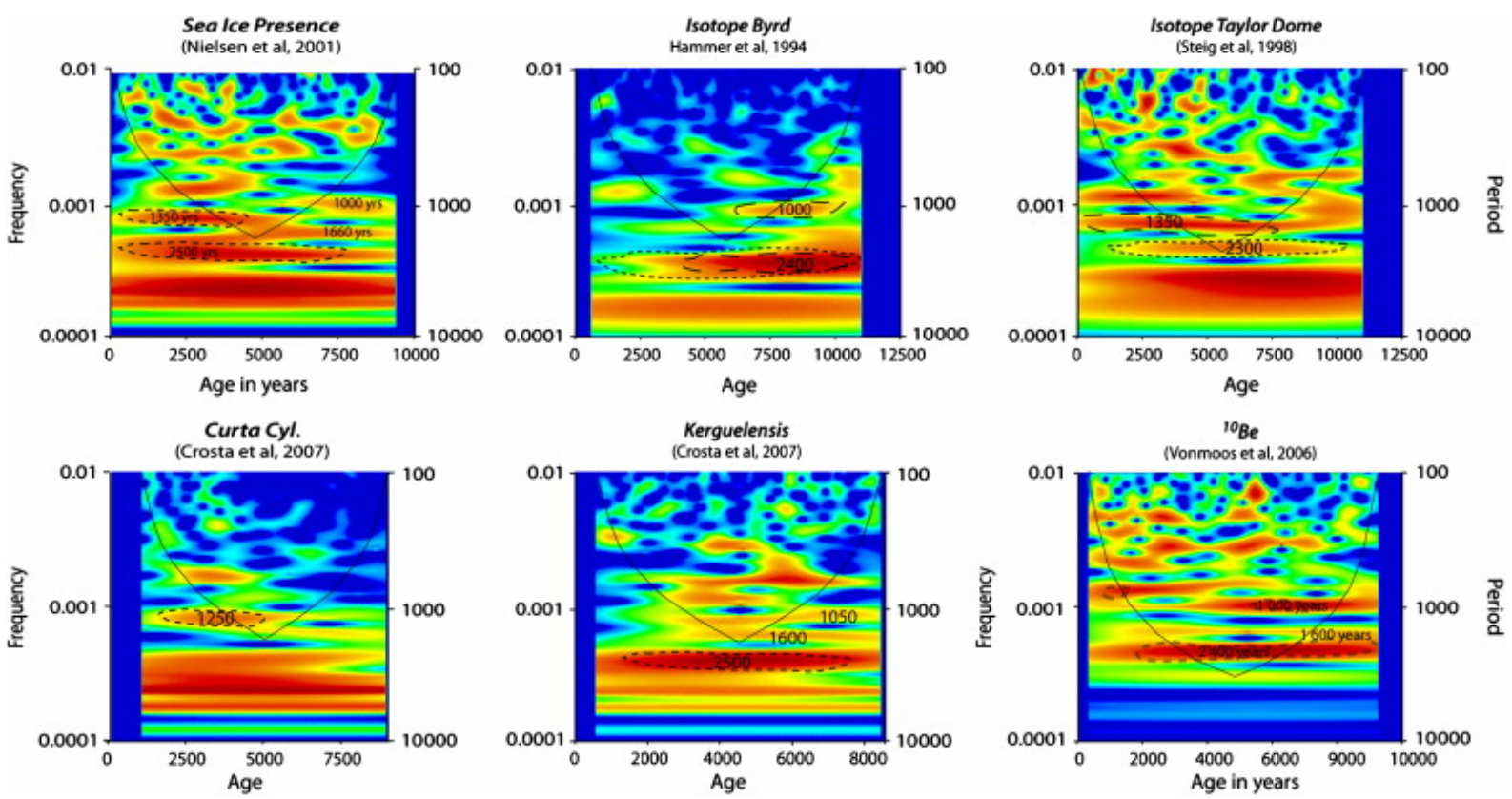

Fig. 6. Wavelet analyses for circum-Antarctic area. Occurrence of the periods (labelled) with respect to the time is given by the bright yellow-red colours. Black line corresponds to cone of influence. Horizontal band corresponding to periodicity higher than 3000 years is not meaningful. The confidence levels are indicated with the dot line: the fine one is $50 \%$ the larger is more than $95 \%$. 

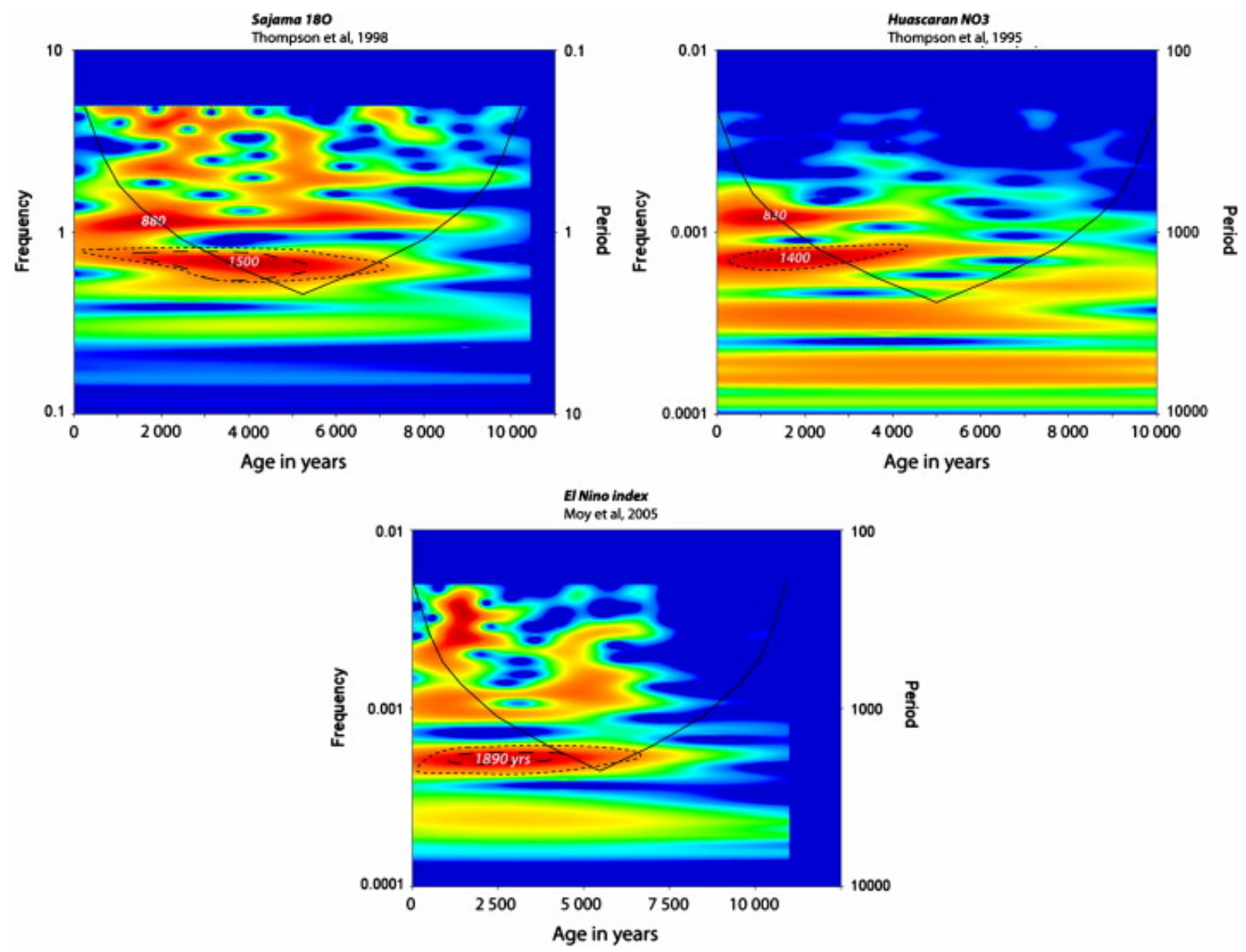

Fig. 7. Wavelet analyses for South America area.

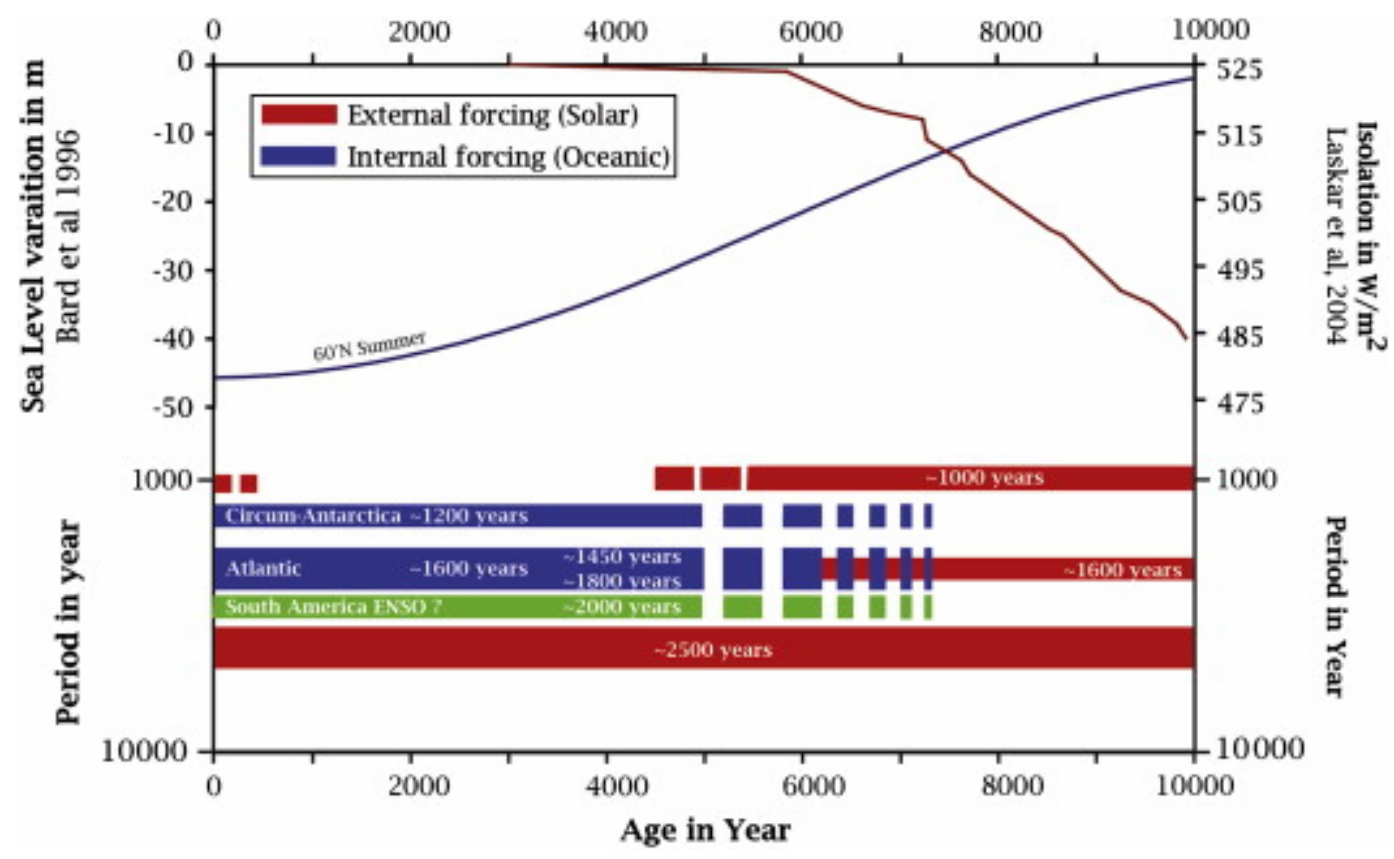


Fig. 8. Holocene frequency pattern based on the study of records from the different areas. It is possible to distinguish internal from external forcing and to identify a strong transition in this pattern around $5000 \mathrm{BP}$. This period is characterised by a sea level close to its maximum and corresponds to the decoupling between methane and insolation.

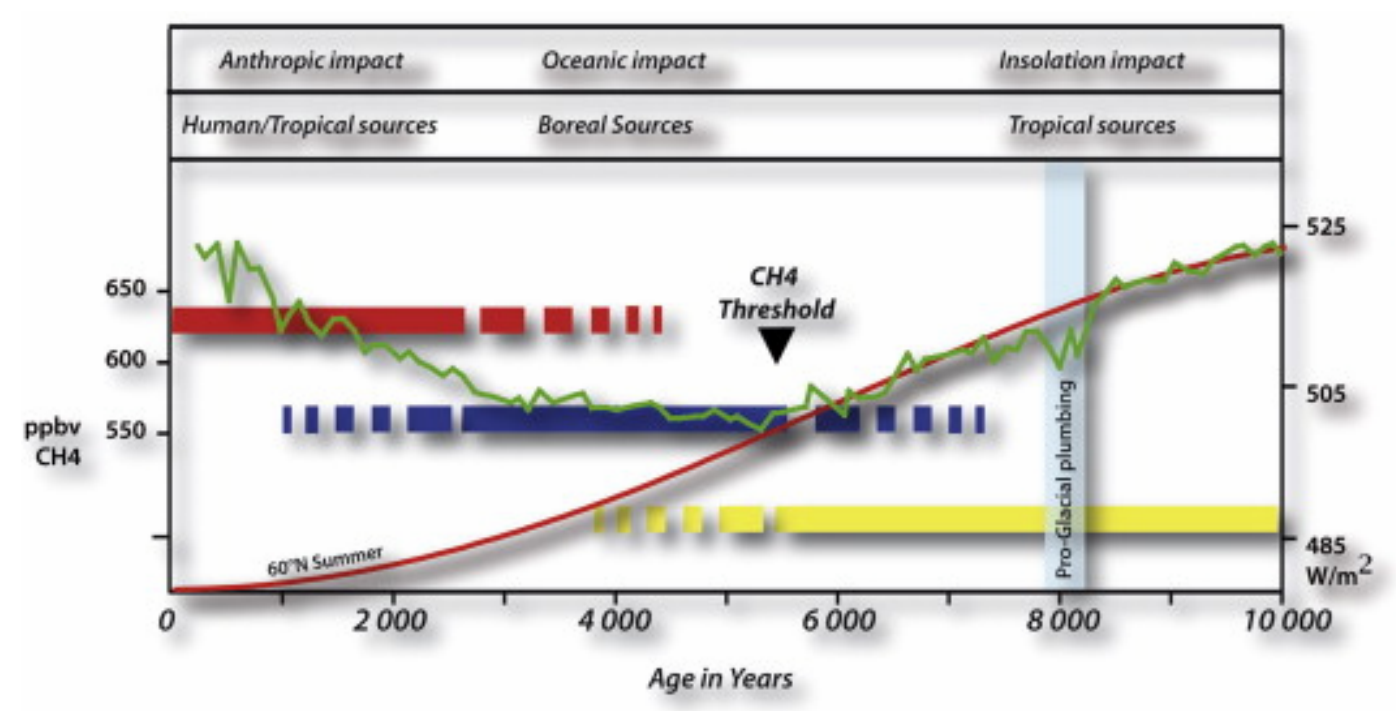

Fig. 9. Methane (in green, Blunier et al., 1995) scenario for Holocene concentration. In the upper part, first line corresponds to impact of different factor on $\mathrm{CH}_{4}$ concentration, second line corresponds to $\mathrm{CH}_{4}$ sources identified by Chappellaz et al. (1997). In the lower part, yellow line reflects insolation forcing, blue line internal forcing, whereas the red one is supposed to be anthropic counterpart on the methane concentration. Vertical blue line is the $8.2 \mathrm{kyr}$ event describes as a pro-glacial lake plumbing. 